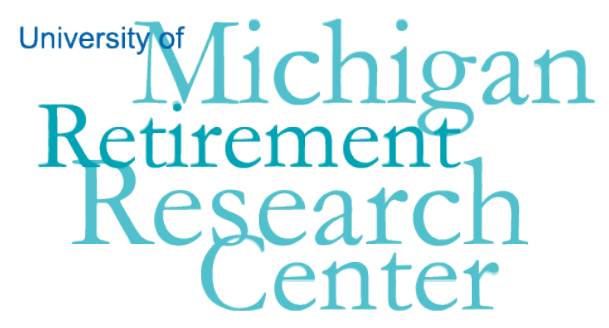

Working Paper WP 2013-286

\title{
Optimal Life Cycle Portfolio Choice with Variable Annuities Offering Liquidity and Investment Downside Protection
}

Vanya Horneff, Raimond Maurer, Olivia S. Mitchell and Ralph Rogalla

\begin{tabular}{|l|l|}
\hline $\mathrm{M}$ & $\mathrm{R}$ \\
\hline $\mathrm{R}$ & $\mathrm{C}$ \\
\hline
\end{tabular}

Project \#: UM13-Q3 



\title{
Optimal Life Cycle Portfolio Choice with Variable Annuities Offering Liquidity and Investment Downside Protection
}

\author{
Vanya Horneff \\ Goethe University \\ Raimond Maurer \\ Goethe University \\ Olivia S. Mitchell \\ Wharton School, University of Pennsylvania \\ Ralph Rogalla \\ Goethe University \\ June 2013 \\ Michigan Retirement Research Center \\ University of Michigan \\ P.O. Box 1248 \\ Ann Arbor, MI 48104 \\ www.mrrc.isr.umich.edu
}

(734) 615-0422

\section{Acknowledgements}

This work was supported by a grant from the Social Security Administration through the Michigan Retirement Research Center (Grant \# 5 RRC08098401-05-00). The findings and conclusions expressed are solely those of the author and do not represent the views of the Social Security Administration, any agency of the Federal government, or the Michigan Retirement Research Center. 


\title{
Optimal Life Cycle Portfolio Choice with Variable Annuities Offering Liquidity and Investment Downside Protection
}

\begin{abstract}
We evaluate lifecycle consumption and portfolio allocation patterns resulting from access to Guaranteed Minimum Withdrawal Benefit (GMWB) variable annuities, one of the most rapidlygrowing financial innovations over the last two decades. A key feature of these products is that they offer access to equity investments with downside protection, hedging of longevity risk, and partially-refundable premiums. Welfare rises since policyholders exercise the product's flexibility by taking withdrawals and dynamically adjusting their portfolios and consumption streams. Consistent with observed behavior, differences across individuals' cash out and annuitization patterns result from variations in realized equity market returns and labor income trajectories.
\end{abstract}

\section{Citation}

Horneff, Vanya, Raimond Maurer, Olivia S. Mitchell, and Ralph Rogalla (2013). “Optimal Life Cycle Portfolio Choice with Variable Annuities Offering Liquidity and Investment Downside Protection." Michigan Retirement Research Center (MRRC) Working Paper, WP 2013-286. http://www.mrrc.isr.umich.edu/publications/papers/pdf/wp286.pdf

\section{Authors' Acknowledgements}

The research reported herein was performed pursuant to a grant from the US Social Security Administration (SSA) to the Michigan Retirement Research Center (MRRC) as part of the Retirement Research Consortium. We are also grateful for research support provided by the TIAA-CREF Research Institute, the German Investment and Asset Management Association (BVI), the Pension Research Council/Boettner Center at The Wharton School of the University of Pennsylvania, and the Metzler Exchange Professor program. This research is part of the NBER programs on Aging, Public Economics, and Labor Studies. All opinions and any errors are solely those of the authors and not of the institutions with whom the authors are affiliated. (C) 2013 Horneff, Maurer, Mitchell, Rogalla. 


\section{Optimal Life Cycle Portfolio Choice with Variable Annuities Offering Liquidity and Investment Downside Protection}

\section{Introduction}

Defined contribution pensions are the most rapidly growing form of retirement saving product around the world. Yet participants in such self-directed pension plans often fail to understand the risks associated with their investment and spending decisions (Lusardi and Mitchell, 2007, 2008), exposing them to the possibility of potential retirement shortfalls (Poterba, Rauh, Venti, and Wise, 2007). Accordingly, households could likely benefit from incorporating income and return guarantees into their defined contribution pension plans (Feldstein, 2009) in addition to improving their financial literacy (van Rooij, Lusardi, and Alessie 2011). Specifically, such products offer lifelong benefit payments during retirement, as well as protection of accumulated assets from downside market shocks. Such guarantees are offered by insurers in the form of investment-linked variable annuities (VAs), though relatively little is known about how to integrate these products into the pension context. This paper shows how such VAs with guarantees can be used to enhance retirement security in the context of a life cycle model.

Variable annuities are one of the most rapidly growing financial products in the past few decades. As of 2010, some $\$ 1.5$ trillion of assets were invested in VA contracts in the U.S. (IRI 2011). By contrast, assets invested in fixed annuities were only $\$ 660$ billion. In the same year, the flow of annuity sales in the U.S. totaled \$210 billion, two-thirds of which were variable annuities. The specific and popular innovation we examine in this paper is a deferred variable annuity with a Guaranteed Minimum Withdrawal Benefit (GMWB) rider; these constitute almost $80 \%$ of recent variable annuity sales (IRI 2011). GMWBs are insurance products with both investment and income components. During the accumulation phase, the policyholder pays premiums to a life insurer, which (after expenses) are invested in mutual fund-style sub-accounts. Then at retirement, the retiree has the possibility of converting her accumulated assets into a lifelong income stream.

In the specific instance of the GMWB, the policyholder may elect to take back her entire premium in small portions (i.e. a "money-back" guarantee) over a certain time frame, regardless of the actual investment performance of her underlying portfolio (Milevsky and Salisbury, 2006). Typically, the consumer may withdraw a maximum percentage of her premium per year until the premium is completely recouped. Any remaining capital at the end of the deferral period can be converted either into a lifelong annuity or paid to the 
policyholder in the form of a lump sum. In this way, the GMWB offers access to equity investments, downside protection against market risk, and the possibility of hedging longevity risk via annuitization. Because of the withdrawal option, premiums are at least in part refundable, so that GMWBs offer also liquidity which can help overcome consumer reluctance to voluntary annuitize retirement wealth. ${ }^{1}$

Prior literature on dynamic portfolio choice has examined household demand for life annuities and its welfare implications. ${ }^{2}$ Though several authors study immediate and fixed annuities, ${ }^{3}$ only a few consider variable annuities with deferred benefits in a realisticallycalibrated lifecycle portfolio choice model. ${ }^{4}$ For instance Horneff, Maurer, Mitchell, and Stamos (2009) investigate gradual annuitization with immediate variable annuities. Brown, Mitchell, Poterba, and Warshawsky (2001) use the utility equivalence concept introduced by Mitchell, Poterba, Warshawsky, and Brown (1999) to evaluate the welfare implications of having access to variable annuities during the decumulation phase. Feldstein and Ranguelova (2001) study variable annuities in an investment-linked Social Security system where households take individual investment risk. Using a continous time framework, Milevsky and Young (2007) allow the retiree to defer annuitization and move his entire savings into a equity-linked annuity as of a single switching date. Recent work by Maurer, Mitchell, Rogalla, and Kartashov (2013) examines variable deferred annuities where payments begin only when the deferring period is over and continue for life. In that context, benefits depend on the performance of the underlying asset portfolio (stocks, bonds, or some combination). Nevertheless, these studies do not account for the guarantees typically included in VAs actually offered in the market.

The research literature on GWMBs is sparse. Recently, Steinorth and Mitchell (2012) evaluate variable annuities with guarantee riders and fees typical of the US annuity market. They conclude that GMWBs are welfare-enhancing for risk-averse consumers, despite the fact that their money's worth ratios are substantially below 100\%. Yet that study focuses only on the decumulation phase. Several other authors have investigated how to price the complex

\footnotetext{
${ }^{1}$ The discrepancy between the theoretical dominance of annuitization predicted by many economists (see originally Yaari, 1965, and more recently Davidoff, Brown, and Diamond, 2005) and the low annuity take-up rates of older households around the world is known as the 'annuity puzzle' (see, e.g., Inkmann, Lopez, and Michaelides, 2011).

${ }^{2}$ Other innovative retirement and saving products recently introduced into lifecycle models include longevity bonds to hedge the systematic mortality risk (Cocco and Gomes, 2012).

${ }^{3}$ See for instance Milevsky and Young (2007), Horneff, Maurer, and Stamos (2008), as well as Huang and Milevsky (2008) who study annuity with immediate fixed payouts within a dynamic portfolio choice model. Horneff, Maurer, and Rogalla (2010) explore deferred annuities with flat benefits.

${ }^{4}$ Xiong, Idzorek, and Chen (2010) provide a simulation analysis of GMWB products with various asset allocations, but this analysis does not embed the product in a life cycle portfolio context.
} 
option features embedded in these contracts. ${ }^{5}$ Milevsky and Salisbury (2006) show that this valuation problem may be traced back to the optimal stopping problem akin to pricing an American put option. Interestingly, they find that variable annuities offered in the North American market are often underpriced. Bauer, Kling, and Russ (2008) develop a generalized pricing formula assuming optimal behavior of policyholders, using risk neutral valuation techniques and efficient numerical procedures.

The present paper extends previous work by incorporating fairly-priced GMWBs into the investment opportunity set of a utility-maximizing investor who faces an uncertain lifetime, as well as risky labor income and equity returns. To price these guarantees, it is important to determine whether the product provider can pool mortality risk, in addition to using techniques from options pricing theory. We allow a CRRA-type investor to buy these products at various points in time during her worklife; she can also take withdrawals until the end of the deferral period (within limits). At retirement, the policyholder can take any remaining assets as a lump sum or she can convert the remainder into a lifetime income stream. The model setup allows us to derive her optimal consumption and portfolio allocation across risky stocks, bonds, and variable annuities of the sort of interest here.

We find that investors will optimally purchase variable annuities prior to retirement because of their flexibility and access to the stock market. Moreover, many consumers will also adjust their portfolios and consumption streams along the way by taking cash withdrawals from the products. Like Chalmers and Reuter (2012), we find that the lump sum option at retirement is exercised when equity returns are higher. Yet unlike that study, which suggests that such withdrawals may be explained by financial illiteracy, we show that differences in households' cash out versus annuitization patterns rationally result from variations in realized cumulative equity market return and labor income trajectories.

In what follows, we first discuss the mechanics and pricing of GMWB annuities. Next, we introduce our life-cycle model and use it to study the optimal consumption and portfolio allocation patterns. Scenario analysis evaluates how demand for and welfare gains due to such products differ with uninsurable labor income uncertainty, as well as with alternative parameterizations of risk aversion, bequest preferences, and wealth levels. Three policy scenarios explore how results depend on taxes, Social Security benefit levels, and deferred annuitization. A final section concludes.

\footnotetext{
${ }^{5}$ Early research in a no-arbitrage framework by Brennan and Schwarz (1976) showed how to price equity-linked variable life insurance policies that provide an asset value guarantee. More recent work includes, among others, Mahayni and Schneider (2012); their products, however, do not provide the withdrawal option characteristic of GMWB annuities.
} 


\section{Mechanics and Pricing of GMWBs}

A single premium deferred variable annuity with a GMWB rider (termed here GMWB for short) is a contract between a life insurance company and an individual consumer who pays the firm an initial amount $A$ at time $t=1$ when signing the contract. The insurance company promises to pay a fixed lifetime benefit stream to the annuitant starting at time $K$, the end of the deferral period. The insurance company invests the premium into a Fund Account $F$ which earns an uncertain growth rate $R_{t+1}$ from time $t$ to $t+1$ and from which the annual fees are deducted. Typically the policyholder can influence the risk-return profile of the investments in the Fund Account by selecting from a menu of mutual funds (e.g. equity, fixed-income, real estate). As with all life-contingent annuity products, if the policyholder were to die during the deferral period, any remaining cash value in the Fund Account is transferred to the insurance company. ${ }^{6}$ But in contrast to traditional deferred life annuities, as long as she is alive, the policyholder may request a return of premium paid to the insurance company, within some limits.

Formally, the development of the Fund Account value $F_{t}(t=1, \ldots, K)$ until the end of the deferral period $(K)$ is given by:

$$
F_{t+1}=\max \left(F_{t}-E_{t}, 0\right) \cdot(1-\varphi) \cdot R_{t+1}
$$

where $F_{1}=A$. Here $E_{t}$ denotes the withdrawal from the Fund Account at time $t\left(E_{1}=0\right)$, and $\varphi$ is the annual expense factor charged by the insurer as a constant percentage of the Fund Account value. A key element of the GMWB is that the insurance company guarantees the policyholder that the sum of all possible (life contingent) withdrawals until the end of the deferral period is at least a certain amount, $\sum_{t=1}^{K} E_{t} \geq E_{1, K}^{\min }$. In our case, this amount is equal to the policyholder's premium paid, $E_{1, K}^{\min }=A$. At the same time, prior to age $K$, periodic withdrawals from the Fund Account are limited to a maximum amount $E_{t} \leq E^{\text {max }}$, typically a fraction of the premium.

The value of the guaranteed minimum withdrawal benefit account is tracked in a special Guarantee Account $G_{t}$, which evolves according to:

\footnotetext{
${ }^{6}$ In the United States and in most European countries, the regulatory framework only allows insurance companies and pension funds to provide annuities with life-contingent payouts. Other important regulated financial institutions such as banks or mutual funds are not allowed to underwrite life-contingent annuities. See Dellinger 2006 (p. 18).
} 


$$
G_{t+1}=G_{t}-E_{t}
$$

Its initial value is defined as $G_{1}=E_{1, K}^{\min }$. Equation (2) shows that the remaining value of the Guarantee Account is given by the value in the previous period minus any withdrawals during the period. Hence the policyholder can decide in each period $t=2, \ldots, K-1$ to withdraw an amount that satisfies the following limits:

$$
0 \leq E_{t} \leq \min \left(G_{t}, E^{\max }\right)
$$

At the end of the deferral period, at time $t=K$, the remaining cash value of the GMWB is given by the value of the Fund Account, $F_{K}$, or the remaining value of the Guarantee Account $G_{K}:$

$$
L_{K}=\max \left(G_{K}, F_{K}\right)
$$

At time $K$, the policyholder may take a final lump sum, $0 \leq L S_{K} \leq L_{K}$, with the remainder $L_{K}-L S_{K}$ transformed into a payout annuity with lifelong fixed benefits.

The insurer is at risk under this contract, since it takes a short position on a (complex) option; for this, it must levy an appropriate risk charge. That is, if the Fund Account becomes depleted $\left(F_{t}=0\right)$ during the deferral period, or, if at the end of the deferral period the remaining Guarantee Account exceeds the Fund Account $\left(F_{K}<G_{K}\right)$, the insurer must pay the shortfall using own resources. Based on standard arguments from option pricing theory and assuming a rational withdrawal strategy by the policyholder, Milevsky and Salisbury (2006) and Bauer, Kling and Russ (2008) have developed efficient numerical solutions to price the GMWB option (see the Appendix A for details).

Using this approach we generate the annual risk charge expressed as a percentage of the Fund Account. This fee must depend on the policyholder's age when the contract is signed (in all cases here, the deferral period ends at age 65), as well on her asset allocation within the product. Here and in what follows, the pricing approach assumes that the participant's Fund Account is fully invested in equities, since that allocation maximizes the value of her guarantee inside the GMWB. Equity log returns are assumed independently normally distributed with a standard deviation of 18\%; additionally the assumed risk-free interest rate is $2 \%$. The maximum guaranteed yearly withdrawal from a GMWB purchased at time $t$ $(t=1, \ldots, K-1)$ for a premium of $A_{t}$ is given by $E^{\max }=\frac{A_{t}}{K-t}$. At time $K, L_{K}=$ 
$\max \left(F_{K}, G_{K}\right)$. For example, a policyholder age 40 (45) buying a GMWB with a deferral period to age 65 may withdraw no more than 4\% (5\%) of her initial premium per year.

As is evident from the solid line in Figure 1, the insurer's annual risk charge for the GMWB rises with age. A policyholder who purchases the contract at age 40 would have to pay an annual yearly fee of 26 bps of her Fund Account per year until the deferral period of age 65. If the buyer were instead age 50, her yearly fee would rise to 64 bps (assuming the same deferral period). And someone who purchased the same policy at age 64 would pay $1080 \mathrm{bps}$, but for only a single year.

\section{[Figure 1 here]}

The risk charge increases with the purchaser's age because it is paid annually instead of as a one-time lump sum; hence the younger buyer pays the charge over more years. Additionally, when a policyholder dies, remaining wealth in the Guarantee and Fund Accounts transfers to the insurer. This generates the well-known mortality credit due to mortality risk pooling, which the insurance company incorporates in calculating the product risk charge. ${ }^{7}$ The dashed line in Figure 1 illustrates the additional risk charge to cover the death benefit. For example, the life-contingent GMWB purchased at age 40, for example, would involve a risk charge of 26 bps versus 72 bps for the death benefit. At age 60, the annual risk charges are 257 bps versus 448 bps.

Finally, it is worth noting that in the context of a life cycle portfolio choice model with incremental annuity purchases, GMWBs bought at different ages must be tracked individually. This is because the risk charges and guaranteed withdrawal amounts permitted from the Fund Accounts vary with the buyer's purchase age. We analyze this process in the next section.

\section{The Life-Cycle Model with Guaranteed Minimum Withdrawal Benefits Annuities}

In this section, we integrate GMWBs into a consumption and portfolio choice life cycle model for a utility-maximizing representative individual having an uncertain lifespan. We work in discrete time, starting at the end of age $39(t=0)$, and we assume that the individual's decision period runs from age $40(t=1)$ to $100(T=61)$. Until retirement, she earns an exogenously-determined labor income $Y_{t}=f(t-1) \cdot P_{t} \cdot U_{t}$, consisting of a deterministic trend $f(t)$ as well as permanent and transitory income components $\left(P_{t}=P_{t-1}\right.$. $N_{t}$ and $U_{t}$, respectively). After retirement, the individual receives a constant fraction of her

\footnotetext{
${ }^{7}$ If, instead, the insurer permitted the policyholder to receive a death benefit prior to time $K$ equal to the cash value remaining, this would rule out the mortality credit, making the product more expensive.
} 
last permanent salary as an annuitized lifelong benefit stream. She may purchase GMWBs from age 40 to 64, and retirement starts at age 65. For all GMWBs regardless of when purchased, the deferral age is 65. After that, annuity benefits are paid to the retiree for life. Hence, we assume an incomplete annuity market. In each period, the goal is to decide how much to consume, to save in stocks and bonds, and (prior to retirement) how much to spend on new GMWBs or withdraw from existing GMWBs.

Preferences: The individual's subjective probability of survival from $t$ until $t+1$ is denoted by $p_{t}^{s}$. Preferences at time $t$ are specified by a time-separable $C R R A$ utility function defined over current consumption $C_{t}$. The variable $Q_{t}$ denotes the level of bequest at time $t+1$ if the decision maker dies between $t$ and $t+1$, and the strength of her bequest motive is controlled by the parameter $b$. The term $\rho$ refers to the coefficient of relative risk aversion, and $\beta$ is the time preference rate. Then the recursive definition of the corresponding value function is given by:

$$
J_{t}=\frac{\left(C_{t}\right)^{1-\rho}}{1-\rho}+\beta E_{t}\left(p_{t}^{S} J_{t+1}+\left(1-p_{t}^{S}\right) b \frac{\left(Q_{t+1}\right)^{1-\rho}}{1-\rho}\right)
$$

As $p_{T}^{S}=0$, terminal utility is given by $J_{T}=\frac{\left(C_{T}\right)^{1-\rho}}{1-\rho}+\beta E_{T}\left(b \frac{\left(Q_{T+1}\right)^{1-\rho}}{1-\rho}\right)$. From the final value, we work backwards to find the optimal policies for consumption, saving, and portfolio allocation over the life cycle.

GMWBs in the Life Cycle Setting: In our life cycle model, the individual has the opportunity to incrementally purchase her GMWB contracts between ages 40 and $64 .^{8}$ As noted above, for each age at which she buys a GMWB policy, a new Fund Account is defined wherein returns (net of fees) minus withdrawals are accumulated until retirement at age 65 . Additionally, for each annuity purchase, a specific Guarantee Account as well as the specific annual maximum withdrawal amount must be tracked. Accordingly, modeling all possible purchases between age 40 and 64 requires following 25 different Fund Accounts, Guarantee Accounts, and withdrawal limits, or 75 accounts in total. Moreover, this also requires deciding how to optimally distribute withdrawals over the (potentially) 25 Fund Accounts. Explicitly keeping track of so many state and decision variables in a dynamic optimization model is

\footnotetext{
${ }^{8}$ Previous work on optimal gradual annuitization with fixed and variable deferred annuities over the lifecycle shows that annuity purchases are negligible before age 40 (Horneff, Maurer, and Rogalla, 2010; Maurer, Mitchell, Rogalla, and Kartashov, 2013).
} 
(currently) unfeasible due to the computational burden. In what follows, we describe a more efficient approximation strategy which we devise for resolving this issue.

Let $F_{i, t}$ denote the value of the Fund Account at time $t$ from a GMWB purchased at time $i \leq t$ for a premium of $A_{i}=F_{i, i}$. Any withdrawal from this account is given by $E_{i, t}$. The yearly fee charged by the insurance company to cover the guaranteed minimum benefits promised to the policyholder is represented by $\varphi_{i}$. Analogous to Equation (1), the Fund Account at time $t$ for this GMWB purchased at time $i$ develops as follows:

$$
F_{i, t+1}=\max \left(F_{i, t}-E_{i, t}, 0\right) \cdot\left(1-\varphi_{i}\right) \cdot R_{t+1}
$$

The corresponding development of the Guarantee Account is given by:

$$
G_{i, t+1}=G_{i, t}-E_{i, t}
$$

At each specific age, the overall values of the various Fund and Guarantee Accounts from all previously-purchased GMWBs as well as the sum of withdrawals from these accounts are given by:

$$
F_{t}=\sum_{i=1}^{t-1} F_{i, t}, \quad G_{t}=\sum_{i=1}^{t-1} G_{i, t}, \quad \text { and } \quad E_{t}=\sum_{i=1}^{t-1} E_{i, t} .
$$

Additionally, we define an expense factor $\Phi_{t}$ that is applied to the total Fund Account to calculate the total risk charge levied by the insurer for all previously-purchased annuities. Accordingly, the value of the total Fund Account evolves as follows (where $E_{1}=F_{1}=0$ ):

$$
F_{t+1}=\left[\max \left(F_{t}-E_{t}, 0\right) \cdot\left(1-\Phi_{t}\right)+A_{t} \cdot\left(1-\varphi_{t}\right)\right] \cdot R_{t+1}
$$

The total Fund Account next period, at time $t+1$, has two parts. The first component represents the individual's current Fund Account value $F_{t}$, accumulated from previous annuity purchases. This value is reduced by withdrawals $E_{t}$ and by annual fees using the expense factor $\Phi_{t}$. The second component consists of her additional annuity purchases $A_{t}$ in the current period, minus the specific risk charge $\varphi_{t}$ at time $t$. Both components grow according to the gross return $R_{t+1}$ earned by the assets backing the annuity. ${ }^{9}$

\footnotetext{
${ }^{9}$ In the simulation analysis using optimal feedback controls, we track the specific subaccounts for the GMWB purchased at different ages; this allows us to apply the specific risk charges. The overall optimal withdrawal
} 
The expense factor $\Phi_{t}$ is defined as a weighted average of the risk charges applied to previous GMWB purchases and the fee levied on any new purchase at time $t$ :

$$
\Phi_{t+1}=\Phi_{t} \cdot x_{t+1}+\left(1-x_{t+1}\right) \cdot \varphi_{t}
$$

The weight $x_{t+1}$ on the previous period's expense factor refers to the current value of previously-purchased annuities divided by the current value of the total Fund Account including new purchases at time $t$. Formally (where $F_{t+1}>0$ ):

$$
x_{t+1}=\frac{\max \left(F_{t}-E_{t}, 0\right) \cdot\left(1-\Phi_{t}\right) \cdot R_{t+1}}{\max \left(F_{t}-E_{t}, 0\right) \cdot\left(1-\Phi_{t}\right) \cdot R_{t+1}+A_{t} \cdot\left(1-\varphi_{t}\right) \cdot R_{t+1}} .
$$

In the first period, the expense factor is $\Phi_{1}=0$; if GMWBs are purchased at $t=1$, the second-period expense factor $\Phi_{2}$ is equal to $\varphi_{1}$. Consequently, in a two-period situation, the formula is exact. In a more general case, our approach represents a very close approximation to the cost structure of a portfolio of gradually-purchased GMWBs with different age-specific risk charges. This permits us to reduce the number of state variables for the GMWB in our backward optimization, from 75 to three. ${ }^{10}$

Finally, the development of the total Guarantee Account is given by the last period's Guarantee Account value, reduced by withdrawals and increased by new GMWB purchases. Before retirement, i.e. $t<K$, the total Guarantee Account is as follows:

$$
G_{t+1}=G_{t}-E_{t}+A_{t}
$$

At retirement, the individual must decide how much of her GMWB value, i.e. $\max \left(F_{K}, G_{K}\right)$, she takes out as a lump sum $L S_{K}$. The remaining amount is converted into a payout annuity with constant lifelong benefits $\left(P A_{K}\right)$ :

amount $E_{t}$ at time $t$ is allocated to specific subaccounts as a percentage calculated according to $E_{i, t}=E_{t}$. $E_{i}^{\max } / \sum_{i=1}^{t-1} E_{i}^{\max }$. Here, $E_{i}^{\max }$ is the maximum allowable withdrawal for subaccount $i$.

10 The approximation results from the fact that, for two annuities purchased at different points in time with risk charges $\varphi_{1}<\varphi_{2}$, the relative importance of the second risk charges decreases over time, while Equation (10) assumes it is constant. Accordingly, $\Phi_{t}$ slightly overestimates the cost. To assess the potential approximation error we proceed as follows. We generate 10,000 life cycle profiles based on the optimal feedback controls using Monte Carlo simulations for the uncertain equity returns and labor income profiles. For each of these 10,000 paths, we calculate the total expense ratios at each age for two cases: (i) using equation (10) and (11), and (ii) using the exact risk charges for the specific accounts. Calculating the differences between the two total expense ratios for each of the 10,000 life cycle paths provides a distribution of the approximation error. Even at age 64, when the approximation error is at its maximum, it merely amounts to 0.29 (0.92) bps at the 50\% (95\%) quantile in the base case. In the sensitivity analysis, the approximation errors are comparably small. 


$$
P A_{K}=\frac{\max \left(F_{K}, G_{K}\right)-L S_{K}}{\ddot{a}_{K}}
$$

where $\ddot{a}_{K}=1+\sum_{s=1}^{\omega-K}\left(\prod_{u=K}^{K+s-1} p_{u}^{a}\right) R_{f}^{-s}$ denotes an actuarial annuity factor at retirement. The year-to-year survival probabilities $p_{u}^{a}$ used to price the annuity are specified by a mortality table with assumed last age $\omega$, and $R_{f}$ is the interest rate used by the insurance company to discount future benefit payments. After the remaining fund value has been converted into a fixed payout annuity with no additional access to guaranteed withdrawals, no future risk charges are levied, i.e. $\Phi_{t}=0(t>K)$. Accordingly, the dynamic portfolio choice problem during the retirement period can be solved using only one state variable to represent the annuity.

Budget Constraints: In each period, the individual may allocate cash on hand $\left(W_{t}\right)$ to consumption ( $\left.C_{t}\right)$, liquid saving in stocks $\left(S_{t}\right)$ and bonds $\left(B_{t}\right)$, and - prior to retirement additional GMWB purchases $\left(A_{t}\right)$. At retirement, cash on hand increases by final lump-sum distributions from the GMWBs $\left(L S_{K}\right)$ and, additionally, by the GMWB annuity payouts $\left(P A_{K}\right)$. Formally, the resulting budget constraints are:

$$
W_{t}= \begin{cases}C_{t}+S_{t}+B_{t}+A_{t} & t<K \\ C_{t}+S_{t}+B_{t}-P A_{K}-L S_{K} & t=K \\ C_{t}+S_{t}+B_{t}-P A_{K} & t>K .\end{cases}
$$

During the worklife, cash on hand next period is given by the value of the stock and bond investments including any returns, labor income $\left(Y_{t}\right)$, and any withdrawals from the previously-purchased GMWBs $\left(E_{t}\right)$. At retirement, labor income is replaced by a constant Social Security benefit stream $\left(Y_{K}\right)$. Formally, the development of cash on hand is given by:

$$
W_{t+1}= \begin{cases}S_{t} R_{t+1}+B_{t} R_{f}+Y_{t+1}+E_{t} & t<K \\ S_{t} R_{t+1}+B_{t} R_{f}+Y_{K} & t \geq K .\end{cases}
$$

Finally, the policies must satisfy the following constraints: 


$$
\begin{gathered}
C_{t}, A_{t}, S_{t}, B_{t} \geq 0 \quad(t<K) \\
0 \leq E_{t} \leq \frac{G_{t}}{K-t} \quad(t<K) ; \quad E_{K} \leq \max \left(F_{K}, G_{K}\right) ; \quad E_{t}=0 \quad(t>K) \\
A_{t}=0(t \geq K) .
\end{gathered}
$$

Numerical Methods and Model Calibration: For calibration of the base case parameters, we use standard values in the literature. We posit a coefficient of relative risk aversion of 5 , and a time discount rate of 0.96. Initially, we also abstract from an intentional bequest motive $^{11}$ and set $b$ to 0 . The risk-free interest rate is $2 \%$, and stock returns are serially independent and log-normally distributed with a mean of $6 \%$ and volatility of $18 \%$. Survival probabilities which enter in the utility function are specified by the U.S. 2000 Basic Population Table. GMWB annuities are priced (as described in Appendix A) using the same mortality table and assuming that the Fund Account is fully invested in equities.

Calibration of the labor income parameters and initial wealth draws on Love (2010) for a single female college graduate. In our base case, the 40 year old single female has liquid wealth of $\$ 120,000$ and earns $\$ 29,600$ per year. Thereafter, her labor earnings profile follows the typical hump-shaped pattern, and she is not exposed to labor income shocks. After retirement at age 65, she receives a combined pension from Defined Benefit (DB) pension plans and Social Security amounting to $73.6 \%$ of her last permanent labor income.

In sensitivity analyses, we assess the impacts of changes in preferences, income, and wealth levels. In policy scenarios, we also examine cases where the pension replacement rate is reduced and where the GMWB may be purchased within a tax-qualified pension account (see Appendix B for details).

The consumer's optimization problem is solved using dynamic stochastic programming. In the base case, we have five state variables prior to retirement: wealth $\left(W_{t}\right)$, the total Fund Account $\left(F_{t}\right)$, the value of the total Guarantee Account $\left(G_{t}\right)$, the expense factor $\left(\Phi_{t}\right)$, and time $(t)$. We discretize the five-dimensional state space using a grid of size $30(W) \times 20(F) \times 20(G) \times 6(\Phi) \times 61(t)$ with equal spacing for $\Phi$ and logarithmic spacing for $W, F$, and $G$. After retirement, we only need to track wealth $(W)$, GMWB annuity income $\left(P_{K}\right)$, and

\footnotetext{
${ }^{11}$ Empirical evidence regarding the existence and the strength of intentional bequest motives is mixed. Hurd (1989) estimates an almost zero intentional bequest preference and concludes that most households have only accidental bequests. In contrast, Bernheim, Shleifer, and Summers (1985) report that many US older persons indicate they have a significant bequest motive. Recent empirical work by Ameriks, Caplin, Laufer, and Nieuwerburgh (2011) for US-households shows that "bequest motives are more prevalent than previously thought.”
} 
time $(t)$. For each grid point, we calculate the optimal policies and value function using quadrature integration and spline interpolation. ${ }^{12}$

\section{Results for the Base Case}

This section describes the consumer's optimal demand for GMWBs over her life cycle. Specifically, we analyze when she optimally purchases annuities during her worklife, and how much she buys. In addition, we investigate how she exercises the GMWB withdrawal options, in reaction to the stock market's uncertain development.

Figure 2 displays results from the base case. The top panel reports the paths of expected consumption, labor income, wealth in liquid assets (stock, bonds) and GMWBs, along with annuity purchases over time and withdrawals from existing GMWB accounts. Here the GMWB value is the greater of either the Fund or the Guarantee Account prior to age 65 , and thereafter the (actuarial) present value of the lifetime annuity payments. We define financial wealth as the sum of stocks, bonds, and GMWB values. In this setting, at age 40, the individual optimally allocates a substantial portion of her financial wealth to the GMWB, about $\$ 48,000$ or $42 \%$. The value of the Fund Account continues to rise during her worklife, peaking at age 64 when it amounts to about $\$ 210,000$ in expectation. At age 65, she takes a lump-sum of about $\$ 17,000$, around $7.4 \%$ of her GMWB value, which is reflected in the sharp increase in liquid wealth. All remaining GWMB assets are converted into a lifelong annuity paying fixed benefits of about $\$ 14,000$ per year, or $49 \%$ of her last labor income. Since no further annuity purchases after age 65 are possible in our model, the present value of the annuitized financial wealth continuously declines with age during retirement.

[Figure 2 here]

The fine dotted line in the top panel of Figure 2 indicates that average consumption is quite smooth over the life cycle. During her worklife, consumption is higher than labor income, with the gap mostly financed by gradually depleting liquid wealth. In retirement, the individual consumes more than her Social Security benefit, with the excess financed mostly by the GMWB annuity, worth about two-thirds of the Social Security benefit. Precautionary saving is low, since there is no labor income risk during the worklife in this base case. As is typical in such models, liquid assets are fully invested in equities at the outset (not shown in the graph), with the equity share declining around half by retirement age. During retirement, since the Fund Account has been converted into a bond-like fixed payout annuity, the

\footnotetext{
${ }^{12}$ Selected policy functions for optimal portfolio choice are presented in Appendix C, Figure A1. These indicate that our results are numerically stable.
} 
remaining liquid assets are fully invested in stocks. Liquid assets are fully depleted around age 85 , on average, due to the lack of a bequest motive.

The bottom panel of Figure 2 shows average annuity purchases (black bars) and withdrawals (clear bars) from existing accounts, as well as the values of the Guarantee (solid line) and Fund Accounts (dashed line). Account values correspond to the left axis, while purchases and withdrawals refer to the right axis.

Focusing first on purchases and withdrawals, we note that when a household buys additional annuities, its corresponding withdrawals amount to zero and vice versa. Purchases (withdrawals) depicted in the figure are generated by averaging over the 10,000 simulated realizations of $A_{t}$ and $E_{t}$, respectively. Hence, at any given age, some households are purchasing new annuities, while others are withdrawing funds.

As noted above, at age 40, individuals on average devote a substantial amount of their financial wealth $(\$ 48,000)$ to the GMWB, which is relatively inexpensive due to the low annual guarantee risk charge of about 26 bps. This high initial annuity purchase, combined with rising fees for additional purchases, produces negligible additional GMWB purchases until just before retirement. Then at age 64, some individuals take advantage of the final annuitization opportunity and shift a small amount of their liquid wealth into the annuity product despite its relatively high fee (around 14.6\%). Other policyholders find it optimal to take small withdrawals from the GMWB Fund Account through age 64. At age 65, unlimited withdrawals are permitted, and on average people withdraw $\$ 17,000$.

Turning to the development of the Fund and Guarantee Accounts, despite small withdrawals from the GMWB, the Fund Account nevertheless continues to grow due to the expected return on stocks in which the assets are invested. The Guarantee Account increases to around age 50 because GMWB purchases exceed withdrawals. Thereafter, it declines indicating that withdrawals from existing GMWBs supersede additional purchases.

The individual's optimal behavior with respect to withdrawing funds from existing GMWBs as well as purchasing additional GMWBs is complex. It depends on the interactions between stock market returns and their impact on the Fund Account, between the Fund and the Guarantee Account values, and the age-dependent fees for the GMWB rider. Figure 3 sheds some light on these interactions by analyzing the optimal behavior for two specific scenarios.

[Figure 3 here] 
negative earnings. Accordingly, the Fund Account rises strongly and hence its value substantially exceeds the declining Guarantee Account with age. Consequently, the put option embedded in the GMWB is well out of the money, and it is unlikely that the option will ever be exercised. Since the annual risk charge is based on the total value of the now-large Fund Account, the investor pays an increasing risk charge (in absolute terms) despite the low value of the guarantee. Seeking to reduce the costs of this portfolio insurance now rendered unnecessary by the bullish equity market, the investor continuously withdraws the maximum feasible amount from the annuity. Accordingly, the Guarantee Account declines monotonically until it is minimal at age 64. Since the maximum withdrawals are small compared to the overall Fund Account value, the latter continues to increase. Finally at age 65, the Fund Account is worth a great deal, which can be converted into a life annuity or taken as a lump sum.

By contrast, Figure 3B depicts the investor's behavior in an unfavorable equity market scenario. As before, high stock returns earned early in life imply that the Fund Account will exceed the Guarantee level; again, the policyholder then withdraws funds from the GMWB to reduce her costs. Yet these withdrawals together with strongly negative equity returns thereafter subsequently reduce her Fund Account value to around the level of the Guarantee Account. As soon as the embedded put option is in the money (age 45 in Panel B), the product once again offers the possibility of downside protection. Moreover, fees are still relatively low, so the individual will undertake additional annuity purchases. Unfortunately the bear market between her late 40s and mid-50s dramatically erodes her Fund Account, making it unlikely that it will again reach or exceed the guarantee level. So despite the bull market during his late 50s and early 60s, the maximum payable from the GMWB is capped at the guarantee. This leads the investor to withdraw the maximum amount possible from the product and invest it in liquid assets: leaving the funds in the GMWB simply incurs risk charges and involves an opportunity cost (in the form of lost interest earnings). Only immediately prior to retirement will this individual move a substantial fraction of her liquid wealth into the GMWB, to benefit from the lifelong income provided by the annuity.

To further illustrate the heterogeneity of outcomes with respect to how people deploy their GMWB accounts at retirement, we report next the distribution of amounts cashed out as well as the annuity income streams purchased at age $65 .{ }^{13}$ As a reminder, this is the age at which the policyholders can access their entire GMWB accounts, should they wish, or be defaulted into the payout life annuity. Table 1 presents the quantiles of amounts cashed out as

\footnotetext{
${ }^{13}$ As this is a highly dimensional problem in terms of state and decision variables, we find it helpful to conduct a statistical analysis instead of providing the usual discussion of policy functions.
} 
well as annuity income chosen, calculated over the 10,000 simulated life cycle paths. At the median, the individual cashes out around $\$ 17,000$ at retirement, with the remainder of her GMWB wealth converted into a lifelong benefit stream of about $\$ 10,300$ per year. All individuals take some periodic annuity income, with the minimum payout of about \$1,350 p.a. In contrast, some $12 \%$ withdraw no cash from their GMWBs.

[Table 1 here]

This raises the question as to what drives this decision. To investigate this issue, Figure 4 relates the levels of GMWB wealth (horizontal axis) and liquid wealth (vertical axis) to the amounts cashed out at retirement (top panel) and the cumulative stock market returns (bottom panel) for all simulation paths. In the top panel, the color of the individual points indicates the amounts withdrawn at age 65, with turquoise (magenta) representing low (high) values as depicted in the color bar to the right of the panel. Those with higher GMWB values (\$500,000 and more) hold virtually no liquid wealth. To diversify their post-retirement portfolios, they take large cash outs, thus retaining access to the stock market while receiving their bond-like payout annuities. While not shown here, the fraction of GMWB wealth cashed out is fairly constant at $8 \%$ for these individuals. At lower GMWB values we see much more dispersion in liquid wealth and cash out patterns. Here, those who hold relatively high liquid wealth compared to their GMWBs already have adequate capital market exposure and, hence, cash out very little at retirement. Conversely, cash outs rise substantially for those having a larger share of their financial wealth in GMWBs. On this side of the GMWB wealth distribution, cash out ratios range from $0 \%-25 \%$.

[Figure 4 here]

To understand why some people arrive at retirement with different fractions of liquid wealth in their portfolios, we investigate the role of their lifetime stock market experiences. Peoples' different equity return paths are summarized using each individual's realized cumulative gross return on stocks between age 40 and 65 , formally $\prod_{t=1}^{25} R_{i, t}$ (i= $1, \ldots, 10,000) .{ }^{14}$ In the bottom panel of Figure 4 , the color of the individual points indicates the individual's cumulative stock return, with turquoise (magenta) representing low (high) values (see color bar to the right). Those who experienced superior cumulative stock market returns, substantially in excess of expectation $\left(4.3=1.06^{25}\right)$, clearly end up with higher GMWB values (\$500,000 and more). Those with the lowest cumulative stock market return are naturally those with lower total financial wealth. Their low GMWB account values and

\footnotetext{
${ }^{14}$ For example, a cumulative gross stock return of 2 indicates that an investment of $\$ 1$ at age 40 doubles by age 65.
} 
larger fractions of liquid assets can be explained by the fact that they took advantage of the GMWB guarantee and cashed out more prior to retirement, as was illustrated in the bottom panel of Figure 3. For those with mid-range GMWBs, the fraction of financial wealth held in liquid form decreases with increasing realized stock returns. Overall, our measure of stock market experience underscores the importance of equity returns as a key driver of cash outs at retirement. $^{15}$

Finally, we analyze how GMWB access affects policyholders' optimal lifetime consumption. To this end, Figure 5 presents the differences between the average consumption per period of individuals in the GMWB world and that of otherwise identical households without access to this annuity product. Results are presented for the full sample of 10,000 simulated households (clear bars), as well as for a subset including only those with the 5\% lowest consumption (black bars). First, looking at the full sample, we find that consumption differences are rather low prior to retirement, ranging between $\pm \$ 300$. During retirement, however, individuals with GMWB access benefit from the lifelong income stream provided by the annuity. Hence, until around age 80 , they can afford to persistently consume $\$ 1,000$ p.a. more than their counterparts in the non-GMWB world. Later in the life cycle, this difference increases even further. For those in the bottom 5\% quantile, the difference in consumption is also high during their worklives. For example, at age 50, people in the GMWB world can consume around $\$ 800$ more, on average. The reason is that in both worlds the individuals in this sub-sample are characterized by highly unfavorable experiences in the stock market. While those without GMWB access see their financial wealth erode through capital market downturns, GMWB holders are protected by the embedded money-back guarantees. The additional consumption is even more pronounced in retirement, when those with GMWBs receive a constant lifelong income from the annuity product and, therefore, depend much less on the development of the stock market.

[Figure 5 here]

To evaluate the total welfare gain associated with the discussed extension of consumption opportunities over the complete life cycle, we compute the individual's certainty equivalent wealth at age 40 by inverting the value function according to $C E_{t}\left(W_{t}, F_{t}, G_{t}, \Phi_{t}\right)=$ $\left((1-\rho) \cdot J_{t}\left(W_{t}, F_{t}, G_{t}, \Phi_{t}\right)\right)^{\frac{1}{1-\rho}}$. Then we calculate the relative change in certainty equivalent wealth when moving from a world without to a world with GMWBs. For our base case, this welfare gain amounts to $1.7 \%$.

\footnotetext{
${ }^{15}$ In a descriptive linear regression of GMWB cash outs on cumulative stock returns, the estimated constant term is $\$ 5,139$ and the slope is $\$ 2,624$ (all coefficients are highly significant), and the $R^{2}$ is 0.54 . Accordingly, our cumulative returns measure accounts for much but not all of the variance in cash outs.
} 


\section{Scenario Analysis}

Next we evaluate how our results respond to alternative assumptions for preferences, wealth, and labor income risk. Results appear in Table 2, where Column 1 replicates the base case. The next three columns show how different household preferences would influence results. In the base case, the coefficient of relative risk aversion, $\rho$, was 5; Columns 2 and 3 of Table 2 report the impact of assuming lower and higher values ( $\rho=3$ and $\rho=7$ respectively). Column 4 provides results with a bequest motive $b$ of 2, instead of 0 as in the baseline. Columns 5 and 6 present alternative calibrations with respect to initial wealth, high $(\$ 240,000)$ and low $(\$ 0)$. Column 7 depicts a scenario where the individual is exposed to labor income risk. Here, we assume that the logs of the permanent and transitory income shocks are uncorrelated and normally distributed according to $\ln \left(N_{t}\right) \sim N\left(-0.5 \sigma_{n}^{2}, \sigma_{n}^{2}\right)$ and $\ln \left(U_{t}\right) \sim N\left(-0.5 \sigma_{u}^{2}, \sigma_{u}^{2}\right)$, with $\sigma_{n}^{2}=0.0169$ and $\sigma_{u}^{2}=0.0418 .{ }^{16}$ The table reports the impact of each experiment on the expected values of the Fund and Guarantee Accounts, as well as equity and bond holdings in liquid wealth. Values are presented as averages over 5-year age bands. We also provide the cash-out ratio (the percentage of the GMWB value taken as a lump sum at age 65), the annuity replacement rate (the payout annuity as a percentage of last labor income), and the welfare gain from having access to the GMWB vs. no access.

\section{[Table 2 here]}

The highly risk averse individual naturally invests less in stock and much more in GMWBs early on, compared to the base case. In her late 40s, she reduces her stock holdings considerably. This is partly to diversify her portfolio into bonds; partly to acquire more GMWBs (as seen from the increment in the Guarantee Account $(\$ 63,400$ to $\$ 78,500)$ ); and partly to finance consumption in excess of labor income. This pattern continues until her mid50s. When the labor income profile turns down, she withdraws from all accounts to smooth consumption. In particular, she exercises the liquidity option in the GMWB for consumption but not for investment purposes. This pre-retirement behavior is similar to but more pronounced than the base case. At retirement, she takes a smaller lump sum and preserves more in the GMWB annuity than the base case individual. Not surprisingly, according to our welfare measure, this highly risk-averse individual is better off having access to the GMWB than in the base case (2.5\% vs. $1.7 \%)$.

\footnotetext{
${ }^{16}$ See Love (2010). As usual in the life cycle literature, we normalize by the permanent income in the case with labor income risk which reduces the complexity of the numerical optimization problem by one state variable.
} 
In her early 40s, the less risk-averse individual invests more in stocks (\$67,000 vs. $\$ 60,000)$, and less of her wealth in GMWBs $(\$ 47,000$ vs. $\$ 54,000)$. This is because the guarantee feature of the annuity product provides a bond-like asset, which is of less interest to such a person. Subsequently, her equity holdings decrease, but by less than in the base case (50\% vs. 80\%). These withdrawals mainly finance her excess consumption and not portfolio reallocations, as she makes virtually no additional bond or GMWB purchases. At age 65, she cashes out a larger share of her GMWB account (13.2\% vs. $7.4 \%)$, producing a lower payout annuity. This is a result of her desire to hold more stocks in her post-retirement portfolio. As one might anticipate, the welfare gain from having access to this GMWB product is small, less than $1 \%$.

Next, we turn to the case with a bequest motive. In her early 40s, such an individual holds much more liquid wealth $(\$ 94,100$ vs. $\$ 60,100)$ and less in GMWBs $(\$ 26,600$ vs. $\$ 59,400)$ than in the base case, in order to leave an inheritance in case of early death. Initially, liquid wealth is mostly held in stocks. As the individual ages, she gradually shifts it into bonds, in order to diversify her allocation of financial resources available for bequests. Despite the need for holding liquid wealth for bequest purposes, her GMWB purchases rise strongly in her late 40s and early 50s, as can be seen from the increases in the Guarantee Accounts. Subsequent withdrawals for consumption purposes are comparably low. At retirement, only $5 \%$ of the GMWB assets are cashed out. The bulk is converted into the payout annuity that amounts to $42.3 \%$ of the last labor income, only $7 \%$ below the base case. Hence, although annuitized assets are no longer available for bequest, even individuals interested in transferring wealth to their heirs value the income certainty and the mortality credit associated with the annuity product. ${ }^{17}$ This is also reflected in welfare gains similar to those in the base case (1.5\% vs. $1.7 \%)$.

When varying initial endowment of financial wealth, both poorer and richer individuals continue to value the GMWB, though both exhibit a relatively lower demand for the product. A less wealthy household, lacking substantial financial resources, must buy into the GMWB product gradually and she does so until her early 60s. Her wealthier peer devotes around $40 \%$ of her initial wealth to GMWBs at age 40 and continues to add to them until age 50. She also holds more of her financial wealth in bonds, compared to the base case individual. This is because the guarantee inside the GMWB fails to provide enough safe stability in the overall portfolio of financial and human capital. Nevertheless, the wealthier

\footnotetext{
${ }^{17}$ This is in line with previous findings on optimal annuitization behavior in the presence of bequest motives. For example, Horneff, Maurer, and Stamos (2008) report optimal expected annuity holdings of more than 60\% of financial wealth for individuals that have a bequest motive of comparable strength as the one assumed here.
} 
individual experiences a greater welfare gain from access to the GMWB, than does her lessfortunate counterpart ( $2.7 \%$ vs. $0.8 \%)$.

Finally, when the individual is exposed to risky labor income, her initial annuity purchases are substantially lower in her 40s than in the base case. A high level of liquid wealth is necessary as a buffer to smooth consumption in the face of possible negative income shocks. While GMWBs provide some liquidity, purchases early in life only allow for small withdrawals (4\% of the guaranteed amount at age 40 , as discussed above), which may be insufficient to offset temporary income drops. Nevertheless, in her late 40s, she already holds about $17 \%$ of her financial wealth in this special deferred annuity product. This contrasts with previous findings in the literature, where individuals of that age shy away from substantial holdings of deferred annuities that lack the withdrawal feature (e.g. Horneff, Maurer, and Rogalla, 2010; Maurer, Mitchell, Rogalla, and Kartashov, 2013).

As labor income risk-related liquidity needs decrease and GMWB liquidity increases, the individual seeks to compensate for her low purchases early in life. In her 50s, she purchases much more GMWBs than the base case individual. This becomes apparent by looking at the changes in the average levels of the GMWB Guarantee accounts, which rise from $\$ 29,700$ at ages $45-49$ to $\$ 136,400$ at ages $55-59$. As a result, from the late-50s on, the level of the GMWB Fund account is higher than that in the base case. To compensate the additional uncertainty due to labor income risk, the individual holds much more bonds throughout her worklife. ${ }^{18}$

At retirement, the cash out ratio is $2 \%$, more than five percent lower than in the base case. At the same time, the annuity replacement rate is $60.2 \%$ compared to $49.1 \%$ in the base case. Since the pension benefit is also a function of risky labor income, the possibility to annuitize GMWB assets is used to enhance retirement security. ${ }^{19} \mathrm{~A}$ welfare gain of $4.3 \%$ indicates that an individual exposed to both labor income and capital market shocks values the access to GMWBs much more than her counterpart who only faces equity risk.

\footnotetext{
${ }^{18}$ This finding is well documented in the literature. For a theoretical discussion in the context of a realistically calibrated lifecycle model see, e.g., Cocco, Gomes, and Maenhout (2005), for an analysis of empirical data see, e.g., Betermier, Jansson, Parlour, and Walden (2012).

${ }^{19}$ In contrast to the base case, annuity incomes are higher and cash outs are lower across the entire distribution of our simulated individuals. One-third takes no cash outs, and even at the median, cash outs only amount to around \$120. As in Figure 4, those with higher GMWB values hold less liquid wealth and cash out more, while those with measurable holdings of liquid wealth cash out little if any. Cumulative stock market returns, however, are less clearly the driver of retirement cash outs, due to the additional influence of labor income risk. In particular, even individuals benefiting from high cumulative stock returns might not take cash outs due to having more liquid wealth. Here, neither a linear regression of cash outs on cumulative stock returns alone nor on both stock returns and the sum of realized labor incomes exhibit measurable explanatory power (adjusted $R^{2}$ around 0.08). Regression coefficients of the cumulative stock return, however, are statistically significantly negative, while the coefficient of labor income is statistically significantly positive.
} 
In conclusion, the special guarantee and liquidity features, as well as the access to the mortality credit in this investment-linked deferred annuity, make this asset class very attractive to the consumers examined here. ${ }^{20}$

\section{Policy Analysis}

This section explores three alternative scenarios of likely policy relevance for an aging society. The first evaluates GMWBs and investment demand in the context of a lower replacement rate from Social Security and private DB pensions: 50\% of the pre-retirement income instead of $74 \%$ in the base case. Such reductions can be expected in the face of widespread pension terminations in the US and the EU. ${ }^{21}$ Our second policy scenario incorporates taxes, allowing the GMWBs to be purchased in a tax-qualified account. For instance, in the US, money accumulates pre-tax in an Individual Retirement Account, and income taxes are levied at withdrawal. Last, we contribute to current policy debate by analyzing the demand for GMWBs if their annuity payouts were deferred until age 85. This is compatible with a focus on pure longevity risk protection, to insure people against running out of money in old age. ${ }^{22}$ Results appear in Table 3.

[Table 3 here]

Compared to the base case, the consumer with a lower old age replacement rate must invest much more in the GMWB, so as to privately generate retirement income protection. In her early 40s, she holds much less stocks and invests about three-quarters of her financial wealth in GMWBs, vs. about one half in the base case. This early GMWB contribution is paired with small withdrawals later in life, generating a $71 \%$ annuity replacement rate, or around $40 \%$ greater than the base case. The fact that the welfare gain is so large, $4 \%$, confirms the value of this product in a more DC-oriented world.

For the tax scenario, we construct a relatively realistic parameterization following the outline of the current US tax rules. As described in Appendix B, we implement a progressive tax system, where the household must pay taxes on labor income and capital gains taxes on

\footnotetext{
${ }^{20}$ In further analyses not reported here in detail, we also study the impact of incorporating death benefits prior to age 65, which makes the product more expensive (see Figure 1). The results are similar to the base case. GMWBs purchases are lower early in the work life and higher just before retirement, while welfare gains are slightly lower.

${ }^{21}$ The US Department of Labor (2012) reports that the number of defined benefit plans has fallen by $54 \%$ between 1975 and 2010, while the number of defined contribution pensions rose by over 200\%. The number of active DB plan participants decreased by $37 \%$ and rose by $554 \%$ for DC plans over the same period.

${ }^{22}$ For instance, at age 55, participants in Singapore's Central Provident Fund must use a portion of their retirement savings to purchase a deferred annuity. The German Riester pension system also requires that retirees use some or all of their assets to buy deferred annuities payable from age 85 .
} 
investments held outside the GMWB. We also posit a tax-qualified account for purchases of annuities (up to an annual maximum); withdrawals are taxed as ordinary income and, when made prior to age 51, with an additional penalty tax of $10 \%$. Compared to the base case, the individual purchases more equity and holds less in the GMWB account. This is because the liquidity option in the GMWB is less appealing due to the income and penalty tax on premature withdrawals. In her 50s, her higher labor income puts her in a higher tax bracket, making tax-deductible GMWB contributions relatively more valuable. Moreover, here new GMWB purchases continue until her 60s, while in the base case she begins to withdraw from age 55. Toward the end of the worklife, the fund account has accumulated $\$ 225,700$. The cash out ratio at retirement is substantially lower than in the base case, as large lump sum withdrawals will be taxed immediately at a high rate due to tax progressivity. Consequently, the after-tax replacement rate from the GMWB is much higher than in the base, $59.9 \%$ vs. 49.1\%. In this environment, having access to GMWB annuities increases welfare by about $4 \%$, twice the amount in the base case.

Finally, we turn to our last policy experiment, where GMWB assets not withdrawn at retirement are fully converted into a deferred annuity with benefit payments commencing only at age 85. In this scenario, the asset allocation behavior over the worklife is similar to our findings for the base case. The most striking difference is the much higher cash out ratio (54.1\% vs. $7.4 \%)$ and the lower annuity replacement rate (35.4\% vs. $49.1 \%)$. With annuities only paying benefits from age 85, the individual heavily relies on liquid wealth to finance her consumption needs over her first 20 years in retirement, so as to smooth consumption over her remaining lifetime. Despite the fact that this pure longevity risk insurance is much more restrictive than the immediate annuity in the base case, the individual still enjoys a positive, albeit small, welfare gain (1\%).

\section{Discussion and Conclusions}

This paper devises a lifecycle consumption and portfolio choice model for an individual who - in addition to stocks and bonds - can gradually purchase fairly-priced deferred variable annuities (GMWBs). Prior to retirement, these offer access to the stock market with investment downside protection and minimum withdrawal benefits. At retirement, they allow the policyholder to completely cash out the accumulated account or convert it into a fixed lifetime income stream. Such variable annuities have been one of the most rapidly growing financial products over the last decades. 
These products contribute to enhanced lifetime utility across a number of scenarios and policy alternatives, compared to an environment without GMWBs. Whereas other studies predict that consumers will wait to buy deferred annuities late in life, here we show that investors optimally purchase measurable amounts of GMWBs well before retirement because of their flexibility and access to the stock market. This finding is consistent with empirical evidence of the growth in variable annuity demand over time (Geneva Association, 2013). Our results indicate that policyholders will exercise this flexibility by taking withdrawals to adjust their portfolios and consumption streams along the way. Nevertheless, at retirement, they also convert much of their accumulated amounts into additional annuities. Moreover, heterogeneity analysis suggests that differences in individuals' cash out and annuitization patterns result from variations in realized cumulative equity market return and labor income trajectories.

We use our model to conduct three policy simulations. The first experiment shows that the individual purchases far more GMWBs and cashes out less if the replacement rate from Social Security and private defined benefit pensions were to drop by a third. The same applies when GMWBs are available in a tax-qualified retirement accounts. If the GMWB required deferring the payout until age 85 in the spirit of pure longevity insurance, the individual cashes out more at retirement to finance consumption until that age. Nevertheless, she still enjoys a welfare gain from access to the product.

This research is of clear relevance to many stakeholders in the retirement community. Financial institutions offering retirement products, such as insurance companies and mutual funds, as well as financial planners, will find our work useful in their efforts to design and market products. Policymakers may also learn from our analysis, given their expressed interest in retirement solutions which integrate lifetime income protection into defined contribution pensions (Iwry and Turner 2009). Because of their many advantages, fairlypriced GMWBs may be a natural candidate as an automatic decumulation mechanism in the defined contribution environment. 


\section{Appendix A: Valuation of GMWB variable annuities}

The valuation of the options incorporated within a GMWB contract is complex, since the policyholder can decide every period whether and how much to withdraw. In addition, mortality aspects as well as the annual payment of risk charges (instead of lump sums) must be taken into consideration. This paper uses the general pricing model of Bauer, Kling, and Russ (2008) assuming a stochastic withdrawal strategy. Hereby a rational investor selects from all possible strategies the withdrawal tactic that maximizes the option-value of the contract.

The value of the contract for a withdrawal strategy $X$ can be represented as follows:

$$
\begin{aligned}
& V_{0}(X)= \\
& \sum_{\theta=1 \theta-1}^{\Theta} p_{x} \cdot q_{x+\theta-1} \cdot E_{Q}\left[e^{-r \Theta}\left(L_{\Theta}(X, \theta)+W A_{\Theta}(X, \theta)\right)\right]+ \\
& { }_{\Theta} p_{x} \cdot E_{Q}\left[e^{-r \Theta}\left(L_{\Theta}(X, \Theta)+W A_{\Theta}(X, \Theta)\right)\right]
\end{aligned}
$$

where ${ }_{\theta} p_{x}$ denotes the cumulative probability to survive from age $x$ (the start of the contract)

to $x+\theta$, and $q_{x+\theta}$ is the probability of an $x+\theta$ year old individual to die over the next year. Mortality risk and financial markets risks are assumed to be independent. $Q$ is the risk-neutral measure, which implies an arbitrage free financial market. Let $W A_{\theta}$ be a general withdrawal account and $L_{\theta}$ be the performance account that is the maximum of the Guarantee and Fund Account at the end of the deferral period at time $\Theta$. The accounts $L$ and $W A$ develop as follows:

$$
\begin{aligned}
& L_{\Theta}=\max \left(G_{\Theta}, A_{\Theta}\right), \\
& W A_{\theta+1}=\left(W A_{\theta}+E_{\theta}\right) \cdot e^{r}, \\
& A_{\theta+1}=\max \left(A_{\theta}-E_{\theta}, 0\right) \cdot \frac{s_{\theta+1}}{s_{\theta}} \cdot e^{-\varphi}, \\
& \frac{s_{\theta+1}}{s_{\theta}}=\exp \left\{\left(r-\frac{v^{2}}{2}\right)+v z_{\theta}\right\}, z_{\theta} \sim N(0,1), \\
& G_{\theta+1}=G_{\theta}-E_{\theta},
\end{aligned}
$$

where $E_{\theta}$ is the withdrawal at time $\theta$, and $r$ is the risk-free interest rate. 
To determine the optimal withdrawal strategy $X$ we have implemented the numerical method of Bauer, Kling, and Russ (2008). In our case, where the policyholder is not permitted to lapse the contract, it is optimal for the investor to always take the full amount permitted. Our optimal strategy is confirmed by a similar approach in Dai, Kwok, and Zong (2008), who studied the optimal withdrawal rate when lapsing is permitted. Here too, the minimum optimal withdrawal was the full withdrawal amount; that is, it was never optimal to not withdraw.

We use quasi-Monte Carlo simulation with 10,000 iterations to determine value of the contract for a withdrawal strategy $X, V_{0}(X)$. To calculate the fee, we use cubic spline interpolation. The table below shows the numerical values of the annual risk charges for GMWBs with and without mortality risk pooling during the accumulation phase (see also Figure 1 in the main text). Mortality rates are specified by the U.S. 2000 Basic Population Table.

[Table A1 here]

\section{Appendix B: GMWB Annuities within a tax qualified pension account}

We integrate a US-type progressive tax system in our model to explore the impact of having access to GMWBs within a qualified (tax sheltered) pension account of the EET type. Here the household must pay taxes on labor income and on capital gains from investments in bonds and stocks. During the worklife, it buys GMWBs worth $A_{t}$ in the tax-qualified account which reduce the taxable income up to an annual maximum amount $D_{t}$. For Individual Retirement Accounts (IRA) in the US, this maximum amount is $\$ 5,000$ for purchases between age 40 and 50, and \$6,000 from age 51 onwards. ${ }^{23}$ Correspondingly, withdrawals $E_{t}$ from the GMWB in the tax-qualified account increase taxable income. During retirement, the individual can no longer purchase GMWBs. Instead, the household may cash out (some of) the accumulated wealth at retirement or convert the (remaining) assets into a lifelong stream of annuity benefits. Both cash outs as well as annuity benefits are taxed as ordinary income. Finally, the household's taxable income is reduced by a general standardized deduction $G D$. For a single household, this deduction amounts to $\$ 5,950$ per year. Consequently, taxable income is given by:

\footnotetext{
${ }^{23}$ If the GMWB annuity is purchased in a company pension plan, e.g. 401(k) plan, the maximum contribution limit is higher. Also some employers make additional ('matching') contribution into the pension accounts of the employees.
} 


$$
\begin{array}{ll}
Y_{t+1}^{t a x}= & \begin{array}{ll}
\max \left[\max \left(S_{t} \cdot\left(R_{t+1}-1\right)+B_{t} \cdot\left(R_{f}-1\right) ; 0\right)+Y_{t+1}-\min \left(A_{t} ; D_{t}\right)+E_{t}-G D ; 0\right] & t<K \\
\max \left[\max \left(S_{t} \cdot\left(R_{t+1}-1\right)+B_{t} \cdot\left(R_{f}-1\right) ; 0\right)+Y_{K}+P_{K}+L S_{K}-G D ; 0\right] & t=K \\
\max \left[\max \left(S_{t} \cdot\left(R_{t+1}-1\right)+B_{t} \cdot\left(R_{f}-1\right) ; 0\right)+Y_{K}+P_{K}-G D ; 0\right] & t>K .
\end{array}
\end{array}
$$

In line with US rules for federal income taxes, our progressive tax system has six income tax brackets. These brackets $i=1, \ldots, 6$ are defined by a lower and an upper bound of taxable income $Y_{t+1}^{\operatorname{tax}} \in\left[l b_{i}, u b_{i}\right]$ and determine a marginal tax rate $r_{i}^{t a x}$. For the year 2012, the marginal taxes rates for a single household are presented Table A2.

\section{[Table A2 here]} by: $:^{24}$

Based on these tax brackets, the household's dollar amount of taxes payable is given

$$
\begin{aligned}
\operatorname{Tax}_{t+1}\left(Y_{t+1}^{\operatorname{tax}}\right)= & \left(Y_{t+1}^{\operatorname{tax}}-l b_{6}\right) \cdot 1_{\left\{Y_{t+1}^{\operatorname{tax}} \geq l b_{6}\right\}} \cdot r_{6}^{\operatorname{tax}} \\
& +\left(\left(Y_{t+1}^{\operatorname{tax}}-l b_{5}\right) \cdot 1_{\left\{l b_{6} \geq Y_{t+1}^{\operatorname{tax}} \geq l b_{5}\right\}}+\left(u b_{5}-l b_{5}\right) \cdot 1_{\left\{Y_{t+1}^{\operatorname{tax}} \geq l b_{6}\right\}}\right) \cdot r_{5}^{\operatorname{tax}} \\
& +\left(\left(Y_{t+1}^{\operatorname{tax}}-l b_{4}\right) \cdot 1_{\left\{l b_{5} \geq Y_{t+1}^{\operatorname{tax}} \geq l b_{4}\right\}}+\left(u b_{4}-l b_{4}\right) \cdot 1_{\left\{Y_{t+1}^{\operatorname{tax}} \geq l b_{5}\right\}}\right) \cdot r_{4}^{\operatorname{tax}} \\
& +\left(\left(Y_{t+1}^{\operatorname{tax}}-l b_{3}\right) \cdot 1_{\left\{l b_{4} \geq Y_{t+1}^{\operatorname{tax}} \geq l b_{3}\right\}}+\left(u b_{3}-l b_{3}\right) \cdot 1_{\left\{Y_{t+1}^{\operatorname{tax}} \geq l b_{4}\right\}}\right) \cdot r_{3}^{\operatorname{tax}} \\
& +\left(\left(Y_{t+1}^{\operatorname{tax}}-l b_{2}\right) \cdot 1_{\left\{l b_{3} \geq Y_{t+1}^{\operatorname{tax}} \geq l b_{2}\right\}}+\left(u b_{2}-l b_{2}\right) \cdot 1_{\left\{Y_{t+1}^{\operatorname{tax}} \geq l b_{3}\right\}}\right) \cdot r_{2}^{\operatorname{tax}} \\
& +\left(\left(Y_{t+1}^{\operatorname{tax}}-l b_{1}\right) \cdot 1_{\left\{l b_{2} \geq Y_{t+1}^{\operatorname{tax}} \geq l b_{1}\right\}}+\left(u b_{1}-l b_{1}\right) \cdot 1_{\left\{Y_{t+1}^{\operatorname{tax}} \geq l b_{2}\right\}}\right) \cdot r_{1}^{\operatorname{tax}},
\end{aligned}
$$

where, for $A \subseteq X$, the indicator function $1_{A} \rightarrow\{0,1\}$ is defined as:

$$
1_{A}(x)=\left\{\begin{array}{l}
1 \mid x \in A \\
0 \mid x \notin A .
\end{array}\right.
$$

In line with US regulation, the individual must pay an additional penalty tax of $10 \%$ on early withdrawals before age $60(t=21)$ :

$$
\operatorname{Tax}_{t+1}\left(Y_{t+1}^{\operatorname{tax}}\right)= \begin{cases}\operatorname{Tax}_{t+1}\left(Y_{t+1}^{\operatorname{tax}}\right) & t \geq 21 \\ \operatorname{Tax}_{t+1}\left(Y_{t+1}^{\operatorname{tax}}\right)+0.1 E_{t} & t<21\end{cases}
$$

\footnotetext{
${ }^{24}$ Here we assume that capital gains are taxed at an equal rate as labor income. Hence, we abstract from the fact that long-term investments may be taxed at a lower rate.
} 
In order to incorporate progressive taxation into our lifecycle model, we assume that all payments are made at the end of the period. Consequently, the new budget equations are given by:

$$
W_{t}= \begin{cases}C_{t}+S_{t}+B_{t}+A_{t} & t<K \\ C_{t}+S_{t}+B_{t} & t \geq K\end{cases}
$$

and

$W_{t+1}= \begin{cases}S_{t} R_{t+1}+B_{t} R_{f}+Y_{t+1}+E_{t}-\operatorname{Tax}_{t+1} & t<K \\ S_{t} R_{t+1}+B_{t} R_{f}+Y_{K}+P_{K}+L S_{K}-\operatorname{Tax}_{t+1} & t=K \\ S_{t} R_{t+1}+B_{t} R_{f}+Y_{K}+P_{K}-\operatorname{Tax}_{t+1} & t>K .\end{cases}$

To make the results comparable to the base case, we adjust the labor income process such that the level of after-tax labor income corresponds to the labor income in the base case.

\section{Appendix C: Asset Allocation Policies}

Figure A1 displays three policy functions for the base case allocations of wealth to GMWBs, stocks, and bonds, for alternative combinations of age and liquid wealth on hand. These assume that no GMWBs have been purchased previously (i.e. $F=G=\Phi=0$ ). All parameters are as reported in notes to Figure 2.

[Figure A1 here] 


\section{References}

Ameriks, J., A. Caplin, S. Laufer, and S. Van Nieuwerburgh. (2011). The Joy of Giving or Assisted Living? Using Strategic Surveys to Separate Public Care Aversion from Bequest Motives. Journal of Finance 66, 519-561.

Bauer, D., A. Kling, and J. Russ (2008). A Universal Pricing Framework for Guaranteed Minimum Benefits in Variable Annuities. ASTIN Bulletin 38, 621 - 651.

Bernheim, B. D. A. Shleifer, and L. H. Summers (1985). The Strategic Bequest Motive. Journal of Political Economy 93, 1045-1076

Betermier, S., T. Jansson, Ch. Parlour, and J. Walden (2012). Hedging Labor Income Risk. Journal of Financial Economics 105, 622-639.

Brennan, M. and E. Schwartz (1976). The Pricing of Equity-Linked Life Insurance Policies with an Asset Value Guarantee. Journal of Financial Economics 3, 195-213.

Brown, J.R., O.S. Mitchell, J.M. Poterba, and M.J. Warshawsky (2001). The Role of Annuity Markets in Financing Retirement. MIT Press, Cambridge, M.A.

Chalmers, J. and J. Reuter. (2012). How Do Retirees Value Life Annuities? Evidence from Public Employees. Review of Financial Studies 25(8): 2601-2634.

Cocco, J.F., F.J. Gomes, and P.J. Maenhout (2005). Consumption and Portfolio Choice over the Life Cycle. Review of Financial Studies 18, 491-533.

Cocco, J. and F. Gomes (2012). Longevity Risk, Retirement Savings, and Financial Innovation. Journal of Financial Economics 103, 507-529.

Dai, M., Kwok, Y.K., and Zong, J., (2008). Guaranteed Minimum Withdrawal Benefit in Variable Annuities. Mathematical Finance 18, 595-611

Davidoff, T., Brown, J., and P. Diamond (2005). Annuities and Individual Welfare. American Economic Review 95, 1573-1590.

Dellinger, J. K. (2006). The Handbook of Variable Income Annuities (John Wiley \& Sons, Inc., Hoboken, New Jersey).

Feldstein, M. and E. Ranguelova (2001). Individual Risk in an Investment-Based Social Security System. American Economic Review 91, 1116-1125.

Feldstein, M. (2009). Reducing the Risk of Investment-Based Social Security Reform. In Social Security Policy in a Changing Environment. Edited by J. Brown, J. Lieberman and D. Wise. Chicago: Chicago University Press, 201-228.

Geneva Association. (2013). Variable Annuities - An Analysis of Financial Stability. The International Association for the Study of Insurance Economics. Geneva.

Horneff, W., R. Maurer, R., and M. Stamos (2008). Life-cycle Asset Allocation with Annuity Markets. Journal of Economic Dynamics and Control 32, 3590-3612. 
Horneff, W., R. Maurer, O.S. Mitchell, and M. Stamos (2009). Asset Allocation and Location over the Life Cycle with Survival-Contingent Payouts. Journal of Banking and Finance 33, 1688-1699.

Horneff, W., R. Maurer, and R. Rogalla, R. (2010). Dynamic Portfolio Choice with Deferred Annuities. Journal of Banking and Finance 34, 2652-2664.

Hurd, M. (1989). Mortality Risk and Bequests, Econometrica, 57, 779-813.

Huang, H. and M. Milevsky (2008). Portfolio Choice and Mortality-Contingent Claims: The General HARA Case. Journal of Banking and Finance 32, 2444-2452.

Inkmann, J., P. Lopez, and A. Michaelides. (2011). How Deep is the Annuity Market Participation Puzzle? Review of Financial Studies 24, 279-319.

Insured Retirement Institute (IRI). (2011). IRI Fact Book. Washington Downloaded 11/11/2012 at: http://irionline.org/resources/article/id/456

Internal Revenue Service (IRS). (2012). Form 1040 (Tax Tables), Tax Table and Tax Rate Schedules. Downloaded 03/12/2013 at: http://www.irs.gov/pub/irs-pdf/i1040tt.pdf.

Iwry, M. and J. Turner (2009). Automatic Annuitization: New Behavioral Strategies for Expanding Lifetime Income in 401(k)s. The Retirement Security Project Working Paper 2009-2. The Retirement Security Project.

Love, D.A. (2010). The Effects of Marital Status and Children on Savings and Portfolio Choice, Review of Financial Studies 23, 385-432.

Lusardi, A. and O.S. Mitchell (2007). Baby Boomer Retirement Security: The Roles of Planning, Financial Literacy, and Housing Wealth. Journal of Monetary Economics. 54, 205224.

Lusardi, A. and O.S. Mitchell (2008). Planning and Financial Literacy: How Do Women Fare? American Economic Review P\&P: 98, 413-417

Mahayni, A. and J. C. Schneider. (2012). Variable Annuities and the Option to Seek Risk: Why Should you Diversify? Journal of Banking and Finance 36, 2417-2428.

Maurer, R., O.S. Mitchell, R. Rogalla, and V. Kartashov. (2013). Lifecycle Portfolio Choice with Systematic Longevity Risk and Variable Investment-Linked Deferred Annuities, forthcoming: Journal of Risk and Insurance.

Milevsky, M. and V. Young. (2007). Annuitization and Asset Allocation. Journal of Economic Dynamics and Control 31, 3138-3177.

Milevsky, M. A. and T. S. Salisbury. (2006). Financial Valuation of Guaranteed Minimum Withdrawal Benefits, Insurance: Mathematic and Economics 38, 21-38.

Mitchell, O.S., J. Poterba, M. Warshawsky, and J. Brown (1999). New evidence on the money worth of individual annuities. American Economic Review 89, 1299-1318. 
Poterba, J., J. Rauh, S. Venti, and D. Wise. (2007). Defined Contribution Plans, Defined Benefit Plans, and the Accumulation of Retirement Wealth, Journal of Public Economics 91, 2062-2086

van Rooij, M., A. Lusardi, and R. Alessie. (2011). Financial Literacy and Stock Market Participation. Journal of Financial Economics 101, 449-472

Steinorth, P. and O.S. Mitchell. (2012). Valuing Variable Annuities with Guaranteed Minimum Lifetime Withdrawal Benefits, Pension Research Council Working Paper 2012-04, The Wharton School, University of Pennsylvania

U.S. Department of Labor. (2012). Private Pension Plan Bulletin Historical Tables and Graphs. Employee Benefits Security Administration. November.

Xiong, J X., T. Idzorek, and P. Chen. (2010). Allocation to Deferred Variable Annuities with GMWB for Life. Journal of Financial Planning 23, 42-50.

Yaari, M. (1965). Uncertain Lifetime, Life Insurance, and the Theory of the Consumer. Review of Economic Studies. 32, 137-150. 
Table 1: Distribution of Cash Outs at Age 65 and

GMWB Annuity Income in the Base Case

\begin{tabular}{cccccc}
\hline & \multicolumn{5}{c}{ Quantile } \\
\cline { 2 - 6 } & $5 \%$ & $25 \%$ & Median & $75 \%$ & $95 \%$ \\
\cline { 2 - 6 } Cash Out Amount $(\$ 000)$ & 0 & 1.63 & 17.17 & 23.62 & 41.49 \\
Annuity Amount $(\$ 000)$ & 3.99 & 6.59 & 10.27 & 16.41 & 33.63 \\
\hline
\end{tabular}

Notes: Distributions based on 10,000 simulated lifecycles using the base case calibration: Risk aversion $\rho=5$; 


\section{Table 2: GMWB Scenario Analysis: Alternative Parameterizations of Preferences and Budget Constraints}

\begin{tabular}{|c|c|c|c|c|c|c|c|}
\hline & $\begin{array}{l}\text { Base } \\
\text { Case }\end{array}$ & $\begin{array}{c}\text { Less } \\
\text { Risk } \\
\text { Averse }\end{array}$ & $\begin{array}{c}\text { More } \\
\text { Risk } \\
\text { Averse }\end{array}$ & $\begin{array}{c}\text { Bequest } \\
\text { Motive }\end{array}$ & $\begin{array}{c}\text { High } \\
\text { initial } \\
\text { wealth }\end{array}$ & $\begin{array}{c}\text { Low } \\
\text { initial } \\
\text { wealth }\end{array}$ & $\begin{array}{c}\text { Labor } \\
\text { Income } \\
\text { Risk }\end{array}$ \\
\hline \multicolumn{8}{|c|}{ A: GMWB Fund Account (\$000) } \\
\hline Age $40-44$ & 59.4 & 52.1 & 69.6 & 26.6 & 88.8 & 2.2 & 6.9 \\
\hline Age $45-49$ & 96.2 & 73.0 & 109.9 & 70.0 & 128.5 & 20.5 & 34.3 \\
\hline Age $50-54$ & 127.9 & 102.5 & 139.8 & 97.8 & 178.9 & 43.2 & 115.6 \\
\hline Age 55-59 & 158.7 & 135.7 & 170.3 & 126.9 & 228.8 & 63.8 & 199.0 \\
\hline Age 60-64 & 192.5 & 175.7 & 203.8 & 159.5 & 278.8 & 83.1 & 247.2 \\
\hline \multicolumn{8}{|c|}{ B: GMWB Guarantee Account (\$000) } \\
\hline Age $40-44$ & 53.5 & 46.6 & 63.4 & 25.2 & 79.4 & 2.1 & 6.5 \\
\hline Age 45-49 & 69.0 & 50.3 & 78.5 & 55.0 & 89.4 & 18.1 & 29.7 \\
\hline Age $50-54$ & 69.3 & 55.4 & 73.4 & 59.9 & 97.1 & 32.6 & 93.6 \\
\hline Age 55-59 & 59.7 & 55.2 & 60.1 & 57.7 & 89.5 & 38.9 & 136.4 \\
\hline Age 60-64 & 44.1 & 51.7 & 40.7 & 50.7 & 68.1 & 38.8 & 126.8 \\
\hline \multicolumn{8}{|c|}{ C: Stock Investment (\$000) } \\
\hline Age $40-44$ & 60.1 & 67.6 & 49.7 & 94.1 & 141.2 & 4.8 & 105.2 \\
\hline Age $45-49$ & 41.9 & 66.0 & 24.1 & 71.3 & 106.5 & 6.3 & 109.8 \\
\hline Age $50-54$ & 31.8 & 62.6 & 13.6 & 65.3 & 65.7 & 10.3 & 75.7 \\
\hline Age 55-59 & 19.4 & 55.2 & 7.1 & 49.2 & 28.7 & 17.2 & 27.9 \\
\hline Age 60-64 & 8.3 & 33.3 & 5.2 & 26.6 & 11.2 & 18.9 & 12.9 \\
\hline \multicolumn{8}{|c|}{ D: Bond Investment (\$000) } \\
\hline Age $40-44$ & 0.0 & 0.0 & 0.6 & 0.0 & 5.8 & 0.0 & 32.8 \\
\hline Age 45-49 & 0.8 & 0.0 & 5.0 & 1.6 & 24.0 & 0.0 & 55.2 \\
\hline Age 50-54 & 4.6 & 0.1 & 11.2 & 9.1 & 40.8 & 0.0 & 58.8 \\
\hline Age 55-59 & 11.3 & 0.7 & 13.7 & 25.1 & 49.8 & 0.1 & 60.3 \\
\hline Age 60-64 & 9.6 & 2.1 & 7.9 & 35.6 & 26.9 & 3.0 & 39.0 \\
\hline \multicolumn{8}{|l|}{ E: Summary Statistics } \\
\hline Cash Out Ratio (\%) & 7.4 & 13.2 & 4.3 & 5.0 & 4.7 & 3.6 & 2.0 \\
\hline Ann. Repl. Rate (\%) & 49.1 & 42.9 & 53.6 & 42.3 & 72.9 & 22.6 & 65.0 \\
\hline Welfare Gain (\%) & 1.7 & 0.9 & 2.5 & 1.5 & 2.7 & 0.8 & 4.3 \\
\hline
\end{tabular}

Notes: Expected values based on 10,000 simulated lifecycles. Reported are average values over 5-year age bands. Base case calibration: risk aversion 5 ; time preference 0.96 ; no bequest motive 0 ; initial liquid wealth (labor income) of $\$ 120,000$ ( $\$ 29,600$ p.a.) at age 40 ; no labor income risk 0 ; retirement age 65; pension replacement rate $73.6 \%$; no taxes; risk-free interest rate $2 \%$; mean stock return $6 \%$; stock return volatility $18 \%$. Comparative static alternative calibrations alter one parameter with the remaining parameters set equal to those in the base case. For alternative calibrations: low replacement rate 50\%; for taxes, GMWB available in tax-qualified account, taxation as described in Appendix B; deferring age 85 means annuitized GMWBs assets pay lifelong annuity benefits from age 85 on. Source: Authors' calculations. 
Table 3: GMWB Policy Analysis

\begin{tabular}{|c|c|c|c|c|}
\hline & $\begin{array}{l}\text { Base } \\
\text { Case }\end{array}$ & $\begin{array}{l}\text { Low } \\
\text { Rep. } \\
\text { Rate }\end{array}$ & Taxes & $\begin{array}{c}\text { Deferring } \\
\text { Age } 85\end{array}$ \\
\hline \multicolumn{5}{|c|}{ A: GMWB Fund Account $(\$ 000)$} \\
\hline Age $40-44$ & 59.4 & 92.1 & 49.2 & 23.2 \\
\hline Age 45-49 & 96.2 & 125.0 & 90.3 & 92.1 \\
\hline Age $50-54$ & 127.9 & 165.8 & 137.8 & 128.4 \\
\hline Age $55-59$ & 158.7 & 211.6 & 186.2 & 158.2 \\
\hline Age $60-64$ & 192.5 & 262.0 & 225.7 & 186.6 \\
\hline \multicolumn{5}{|c|}{ B: GMWB Guarantee Account (\$000) } \\
\hline Age $40-44$ & 53.5 & 82.4 & 44.4 & 22.1 \\
\hline Age 45-49 & 69.0 & 85.1 & 67.0 & 75.9 \\
\hline Age $50-54$ & 69.3 & 85.3 & 83.3 & 81.9 \\
\hline Age 55-59 & 59.7 & 77.8 & 87.0 & 71.8 \\
\hline Age $60-64$ & 44.1 & 62.0 & 69.5 & 51.6 \\
\hline \multicolumn{5}{|c|}{ C: Stock Investment (\$000) } \\
\hline Age $40-44$ & 60.1 & 33.0 & 68.3 & 97.8 \\
\hline Age $45-49$ & 41.9 & 31.6 & 43.8 & 48.5 \\
\hline Age $50-54$ & 31.8 & 29.5 & 23.1 & 33.3 \\
\hline Age 55-59 & 19.4 & 16.3 & 9.8 & 20.4 \\
\hline Age $60-64$ & 8.3 & 8.0 & 3.2 & 12.2 \\
\hline \multicolumn{5}{|c|}{ D: Bond Investment (\$000) } \\
\hline Age $40-44$ & 0.0 & 0.0 & 0.4 & 0.0 \\
\hline Age $45-49$ & 0.8 & 0.0 & 3.2 & 1.2 \\
\hline Age $50-54$ & 4.6 & 3.4 & 7.5 & 5.9 \\
\hline Age 55-59 & 11.3 & 15.7 & 7.8 & 12.5 \\
\hline Age $60-64$ & 9.6 & 15.1 & 4.3 & 10.5 \\
\hline \multicolumn{5}{|l|}{ E: Summary Statistics } \\
\hline Cash Out Ratio (\%) & 7.4 & 2.7 & 4.8 & 54.1 \\
\hline Ann. Repl. Rate (\%) & 49.1 & 71.0 & 59.9 & 35.4 \\
\hline Welfare Gain (\%) & 1.7 & 4.0 & 4.0 & 1.0 \\
\hline
\end{tabular}

Notes: Expected values based on 10,000 simulated lifecycles. Reported are average values over 5-year age 
Table A1: Annual Risk Charges of Single Premium GMWBs for Alternative Purchase Ages

\begin{tabular}{|c|c|c|c|c|c|c|c|c|c|c|c|c|c|}
\hline \multicolumn{14}{|c|}{ A. Risk Charge per annum (in \%) without mortality risk pooling } \\
\hline Age & 40 & 41 & 42 & 43 & 44 & 45 & 46 & 47 & 48 & 49 & 50 & 51 & 52 \\
\hline Charge & 0.72 & 0.77 & 0.82 & 0.88 & 0.94 & 1.00 & 1.06 & 1.14 & 1.23 & 1.33 & 1.44 & 1.57 & 1.71 \\
\hline Age & 53 & 54 & 55 & 56 & 57 & 58 & 59 & 60 & 61 & 62 & 63 & \multicolumn{2}{|c|}{64} \\
\hline Charge & 1.87 & 2.06 & 2.28 & 2.55 & 2.88 & 3.28 & 3.80 & 4.48 & 5.43 & 6.84 & 9.25 & \multicolumn{2}{|c|}{14.60} \\
\hline \multicolumn{14}{|c|}{ B. Risk Charge per annum (in \%) with mortality risk pooling } \\
\hline Age & 40 & 41 & 42 & 43 & 44 & 45 & 46 & 47 & 48 & 49 & 50 & 51 & 52 \\
\hline Charge & 0.26 & 0.29 & 0.32 & 0.34 & 0.37 & 0.40 & 0.44 & 0.48 & 0.53 & 0.58 & 0.64 & 0.70 & 0.78 \\
\hline Age & 53 & 54 & 55 & 56 & 57 & 58 & 59 & 60 & 61 & 62 & 63 & \multicolumn{2}{|c|}{64} \\
\hline Charge & 0.87 & 0.98 & 1.11 & 1.27 & 1.48 & 1.74 & 2.09 & 2.57 & 3.26 & 4.34 & 6.27 & \multicolumn{2}{|c|}{10.80} \\
\hline
\end{tabular}

Notes: Annual risk charges in basis points (bps) of the current Fund Account value. The Fund Account is assumed to be fully invested in equities with a volatility of $18 \%$, the risk-free rate is $2 \%$, and the deferral period ends at age 65. Source: Authors' calculations.

Table A2: Federal Income Tax Brackets for Singles in 2012

\begin{tabular}{llc}
\hline Lower Bound & Upper Bound & Marginal Tax Rate \\
\hline$\$ 0$ & $\$ 8,700$ & $10 \%$ \\
$\$ 8,701$ & $\$ 35,350$ & $15 \%$ \\
$\$ 35,351$ & $\$ 85,650$ & $25 \%$ \\
$\$ 85,651$ & $\$ 178,650$ & $28 \%$ \\
$\$ 178,651$ & $\$ 388,350$ & $33 \%$ \\
$\$ 388,351$ & --- & $35 \%$ \\
\hline
\end{tabular}

Source: IRS (2012). 
Figure 1: Annual Risk Charges of Single Premium GMWBs at Alternative Purchase Ages

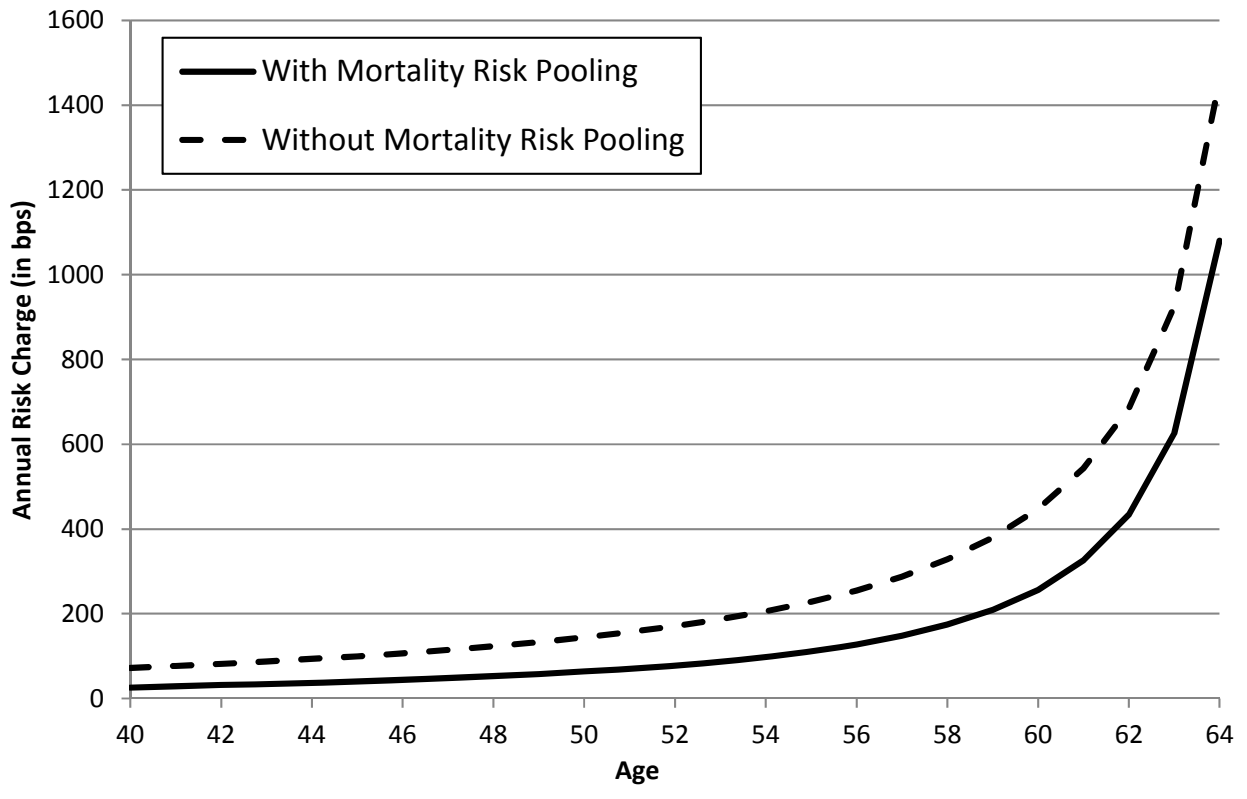

Notes: Annual risk charges in basis points (bps) of the current Fund Account value. The Fund Account is assumed to be fully invested in equities with a volatility of $18 \%$, the risk-free rate is $2 \%$, and the deferral period ends at age 65. The solid (dashed) line represents the situation when the risk charge is calculated with (without) mortality risk pooling. Details are provided in Appendix A. Source: Authors' calculations. 
Figure 2: Expected Life Cycle Profiles in the GMWB Environment
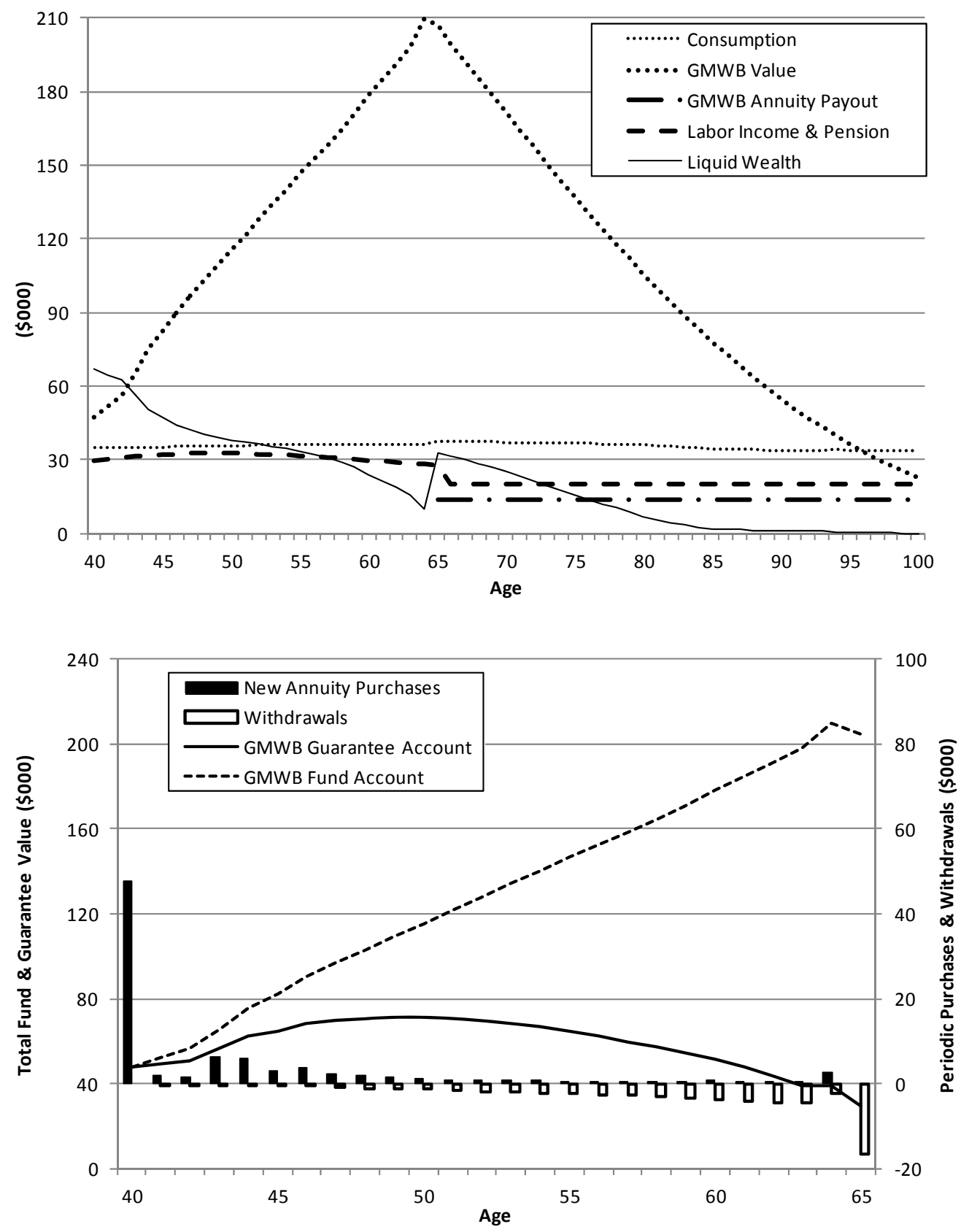

Notes: The top panel shows the development of labor/pension income, liquid and GMWB wealth, GMWB annuity income, and optimal consumption as explained in the text. The bottom panel displays the development of the fund and the guarantee account, as well as the optimal purchases and withdrawals from the GMWB account. Expected values (in $\$ 000$ ) based on 10,000 simulated lifecycles using the base case calibration: risk aversion $\rho=5$; time preference $\beta=0.96$; no bequest motive $(b=0)$; initial liquid wealth (labor income) of $\$ 120,000$ ( $\$ 29,600$ p.a.) at age 40 ; no labor income risk $\left(\sigma_{u}^{2}=\sigma_{n}^{2}=0\right)$; retirement age: 65 ; pension replacement rate $73.6 \%$ no taxes; risk-free interest rate $2 \%$; mean stock return $6 \%$; stock return volatility $18 \%$. Source: Authors' calculations. 
Figure 3: Two Illustrative Examples of the Paths of Equity Returns and GMWB Account Values to Age 65
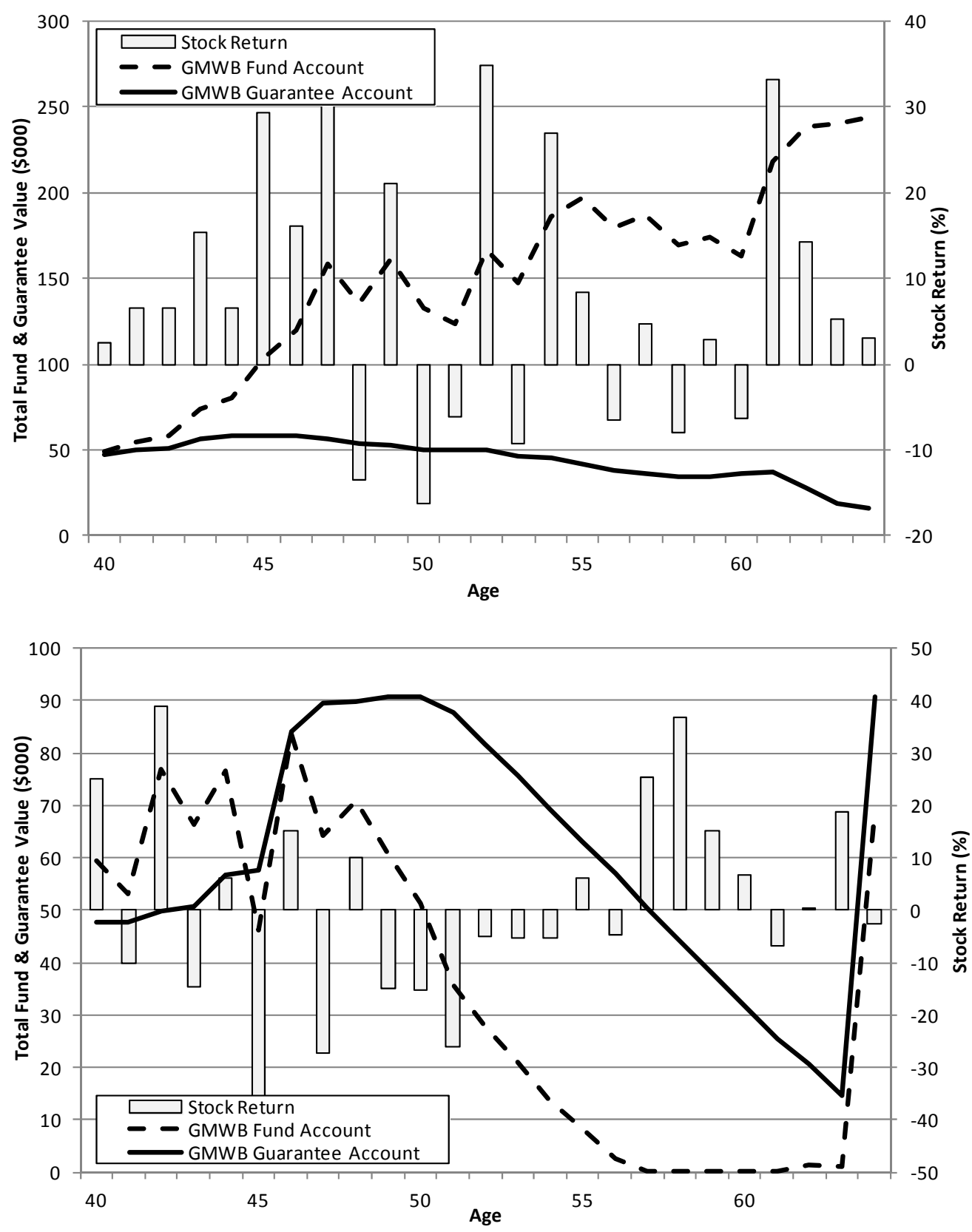

Notes: Each panel presents the development of the GMWB fund and guarantee accounts (in $\$ 000$, left axis) as well as the realized stock returns (in \%, right axis) for one selected simulated lifecycle trajectory using the base case calibration: Risk aversion $\rho=5$; time preference $\beta=0.96$; no bequest motive $(b=0)$; initial liquid wealth (labor income) of $\$ 120,000(\$ 29,600)$ at age 40 ; no labor income risk $\left(\sigma_{u}^{2}=\sigma_{n}^{2}=0\right)$; retirement age 65 ; pension replacement rate $73.6 \%$; no taxes; risk-free interest rate $2 \%$; mean stock return $6 \%$; stock return volatility $18 \%$. Source: Authors' calculations. 
Figure 4: Heterogeneity Analysis: Cash Out Pattern at Age 65
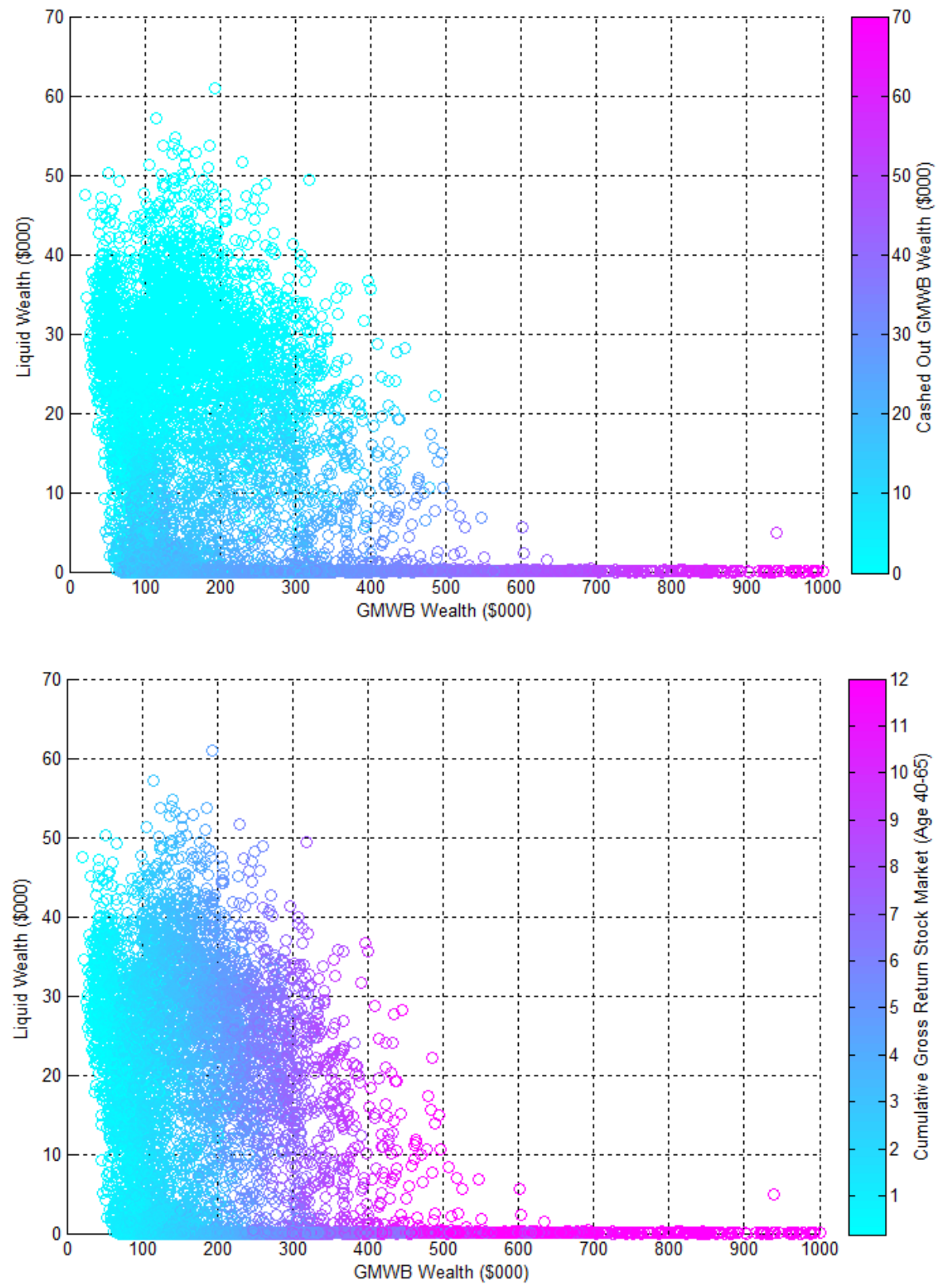

Notes: The top panel shows the amount cashed out of the GMWB at age 65 in relation to the total GMWB (xaxis) and liquid (y-axis) wealth available. The bottom panel shows the realized cumulative gross stock market return from age 40 to age 65 in relation to the total GMWB (x-axis) and liquid (y-axis) wealth available at age 65. Each circle represents one of the 10,000 simulated lifecycles, and its color represents the amount cashed out (the cumulative stock return) - from low (turquoise) to high (magenta). Base case calibration: risk aversion $\rho=5$; time preference $\beta=0.96$; no bequest motive $(b=0)$; initial liquid wealth (labor income) of $\$ 120,000$ ( $\$ 29,600$ p.a.) at age 40 ; no labor income risk $\left(\sigma_{u}^{2}=\sigma_{n}^{2}=0\right)$; retirement age 65 ; pension replacement rate $73.6 \%$; no taxes; risk-free interest rate $2 \%$; mean stock return $6 \%$; stock return volatility $18 \%$. Source: Authors' calculations. 
Figure 5: Impact of GMWB Access on Average Consumption

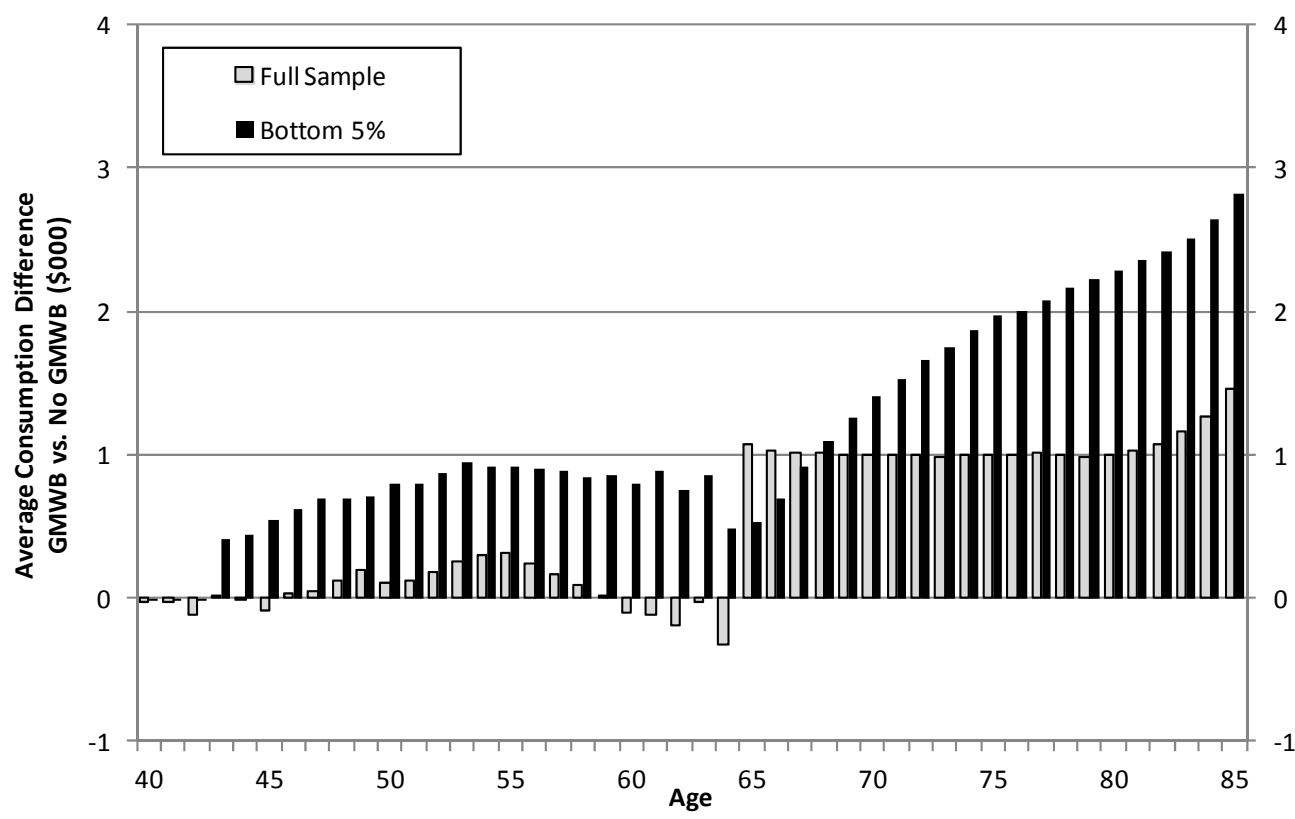

Notes: Differences in average consumption of (otherwise identical) individuals in a world with access to GMWBs compared to a non-GMWB world over time. Full Sample (gray bars): average consumption in both worlds calculated over all 10,000 simulated lifecycles. Bottom 5\% (black bars): average consumption in both worlds calculated over those 500 simulated lifecycles that -at the respective age-exhibit the lowest consumption. Base case calibration: risk aversion $\rho=5$; time preference $\beta=0.96$; no bequest motive $(b=0)$; initial liquid wealth (labor income) of $\$ 120,000(\$ 29,600)$ at age 40 ; no labor income risk $\left(\sigma_{u}^{2}=\sigma_{n}^{2}=0\right)$; retirement age 65; pension replacement rate $73.6 \%$; no taxes; risk-free interest rate $2 \%$; mean stock return $6 \%$; stock return volatility: 18\%. Source: Authors’ calculations. 


\section{Figure A1: Asset Allocation Policy Functions}
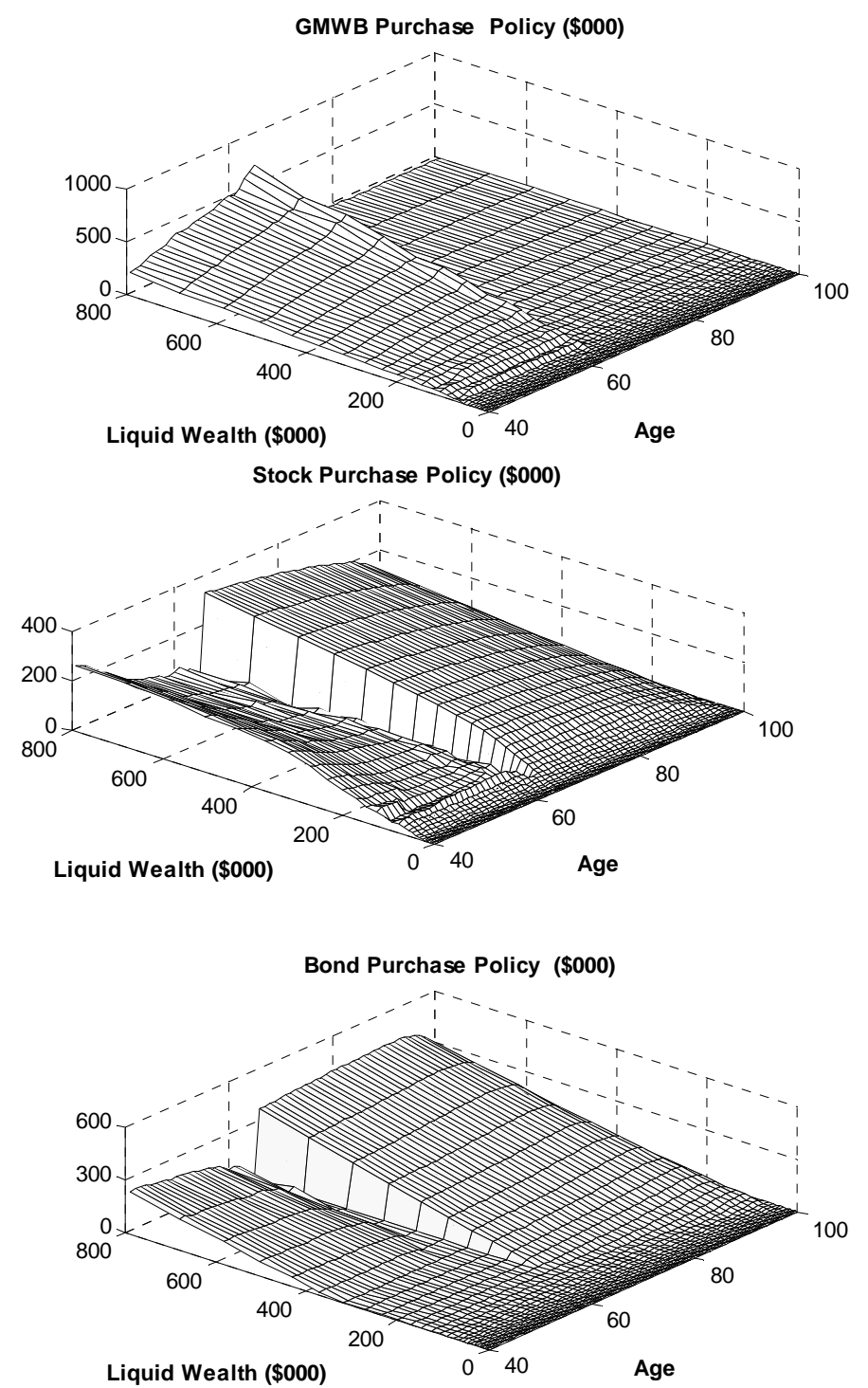

Notes: Policy functions for allocations of wealth to GMWBs, stocks, and bonds for alternative combinations of age and liquid wealth on hand, assuming that no GMWBs have been purchased previously (i.e. $F=G=\Phi=0$ ). Base case calibration: risk aversion $\rho=5$; time preference $\beta=0.96$; no bequest motive $(b=0)$; initial liquid wealth (labor income) of $\$ 120,000$ (\$29,600 p.a.) at age 40 ; no labor income risk $\left(\sigma_{u}^{2}=\sigma_{n}^{2}=0\right)$; retirement age 65 ; pension replacement rate $73.6 \%$; no taxes; risk-free interest rate $2 \%$; mean stock return $6 \%$; stock return volatility $18 \%$. Source: Authors' calculations. 